University of Louisville

ThinkIR: The University of Louisville's Institutional Repository

Electronic Theses and Dissertations

1937

\title{
A guide to Hamlet criticism.
}

Helen Moran

University of Louisville

Follow this and additional works at: https://ir.library.louisville.edu/etd

Part of the Literature in English, British Isles Commons

\section{Recommended Citation}

Moran, Helen, "A guide to Hamlet criticism." (1937). Electronic Theses and Dissertations. Paper 1842. https://doi.org/10.18297/etd/1842

This Master's Thesis is brought to you for free and open access by ThinkIR: The University of Louisville's Institutional Repository. It has been accepted for inclusion in Electronic Theses and Dissertations by an authorized administrator of ThinkIR: The University of Louisville's Institutional Repository. This title appears here courtesy of the author, who has retained all other copyrights. For more information, please contact thinkir@louisville.edu. 


\title{
UNIVERSTTY OF LOUISVILIE
}

A GUIDE TO HAMIET C R I T I C I S M

\author{
A Dissertation \\ Submitted to the Faculty \\ of the Graduate School of the University of Louisville \\ In Partial Fulfiliment of the \\ Requirements for the Degree \\ of Master of Arts
}

Department of English

By

Helen fioran

Year

1937

42543 
Name of Student:

Title of Thesis: A GUIDE TO HAULET CRITICISH

Name of Director:

Approved by a reading committee composed of

the following members:

Representative of the English Department:

Date: $2 \operatorname{2ay} 29,1937$ 
A G U I D E T O HAMIET C R I T I C I S M 
T A B L E O F C O N T E N T S 
page

Preface

v

Chapter I The Shifting Trends in

1

Shakespeare Criticism

II The Origin and Development

of the Early Romantic

Criticism of Hamlet

$(1784-1900)$

III The Realists' Hamlet

41

$(1866-1936)$

23

IV The Twentieth Century

Romanticists' Hamlet

75

Conclusion

98

Bibliography

105 
A Guide to "Hamlet" Criticism is the story of the after-Iife of Shakespeare's tragic hero. The student who has unlimited leisure will find in Augustus Ralli's A History of Shakespearian Criticism a summary of hundreds of analyses; in the two Hamlet volumes of the Variorum Shakespeare, edited by Horace Howard Furness, all the opinions expressed from Shakespeare's day through 1876; and in Anton A. Raven's A "Hamlet" Bibliography and Reference Guide, a list of all writings about Hamlet from 1877 through 1935. In view of the facts that Ralli's history is an outline of general shakespeare criticism; that F'urness presented the criticism in chronological order with no attempt to digest or classify it; and that, although criticism of the play since Furness is available, it, too, has not been organized, I have felt the necessity of a guide through the overwhelming mass of Hamlet material.

In the criticism of the play, I have found three central points of view - the subjective approach of the nineteenth century romantic critic; the spirit of realism, which turned the critic's mind to the sources of Shakospeare's plot and to the traditions of the Elizabethan stage in the late nineteenth century and 
which is manifest in the contemporary historical criticism; and the new romanticism, wich has been tempered by the hard facts contributed by the scholar. Since it is possible to understand the century and a half of Hamlet criticism only against the background from which it has emerged, I have included a general outline of Shakespeare criticism.

Briefly, then, I submit the following plan:

In Chapter I, I shall point out the shifting trends in Shakespeare criticism through three centuries.

In Chapter II, I shaIl indicate the origin and follow the development of the romantic attitude towards the character of Hamlet in the late eighteenth and through the nineteenth century •

In Chapter III, I shall trace the rise of the modern realistic criticism of the play and the twentieth century developments in the method of approach.

In Chapter IV, I shall present the view of the modern subjective critics.

In the Conclusion, I shall formulate my opinion concerning the contributions of these critics towards a better understanding of the play. 
Chapter I

THE SHIFIING TRENDS IN SHAPESPEARE CRITICISM 
THE SHIFTING TRENDS IN SHAKESPEARE CRITICISM

The reader of Shakespeare criticism may begin with Bradley's analysis of the substance of Shakespearean 1 tradedy or with Coleridge's discussion of Hamlet's character, with Professor stoll's starting proof that the soliloquies are not to be taken at face value or with Evelyn's statement, "I saw Hamlet, Prince of Denmark played, but now the old plays began to disgust this refined age." ${ }^{4}$ Wherever and whenever he begins, however, ultimately he will wish to go back to Shakespeare's day and trace through the centuries the shifting trends in the criticism of his plays. Ultimately he will realize that he cannot understand Coleridge's psychological approach to the study of character without some knowledge of his eighteenth century predecessors In the same fleld, and that he cannot appreciate the remedial asperity of stoll unless he knows whattendency has sharpened that scholar's pen and point of view.

It is probable that almost all of Shakespeare's contemporaries failed to appreciate the high character of his art and to value him for it; but we have the "

1. Bradley, A. C., Shakespearean Tragedy, Chapter I

2. Coleridge's Shakespeare Criticism, Edited by Raysor, Thos. M.

3. Stoll, Elmer Edgar, Art and Artifice in Shakespeare, p. 94

4. Twelve Centuries of English Prose and Poetry, Edited by Newcomer and Andrews, p. 301 - from The Diary of John Evelyn, Edited by Bray, William, p. 280 
popular estimate of his work in the opinion of Francis

Meres, who was evidently a regular patron of the players.

In his Palladis Tamia, Wits Treasury, appeared a sketch

called "A comparative discourse of our English Poets,"

in which he sald of Shakespeare:

As Plautus and Seneca are accounted the best for Comedy and Tragedy among the Latines, so Shakespeare among the English is the most excellent in both kinds for the stage; for Comedy, witness his Gentlemen of Verona, his Errors, his Love labours lost, his Love labours wonne, his Midsummers night dreame, and his Merchant of Venice; for Tragedy his Richard the 2 , his Richard the 3 , Henry the 4 , King, John, Titus Andronicus, and his Romeo and Juliet.

As Meres seems to have possessed little critical acumen, however, we had best turn to Shakespeare's fellow dramatist, Ben Jonson, who spoke with the weight of the accepted poet of learning and art.

The Players (Heminge and CondeIl, editors of the First Folio Edition, published in 1623) have often mentioned it as an honour to shakespeare, that in his writing, he never blotted out line, My answer hath been, would he had blotted a thousand...... Hee was (indeed) honest, and of an open and free nature: had an excellent Phantsie; brave notions, and gentle expression: wherein hee flowed with that facility, that sometime it was necessary he should be stop'd. His wit was in his owne power; would the rule of it had beene so too.

1. Tolman, A. H. Falstaff and Other Shakespearean Topics, p. 1777

2. The Great Critics, Edited by Smith and Parks, pp. 213-214 
This dictum that Shakespeare wanted art served, with variations, as the theme of neo-classical criticism, "But hee redeemed his vices with his vertues. There was ever more in him to be praysed, then to be pardoned." ${ }^{1}$ Jonson's estimate, which has been echoed by critics through succeding generations even in those periods when Shakespeare's stock has been lowest, Milton expressed more memorably perhaps in L'Allegro:



In the next generation Dryden described Shakespeare as "the man who of all modern, and perhaps ancient, poets had the largest and most comprehensive soul." Admitting some of those defects in art which Jonson had pointed out, Dryden said, "He is many times flat, insipid; his comic wit degenerating into clenches; his serious, swelling into bombast." He added, however, "But he is always great when some great occasion is presented to him; no man can say he ever had a fit subject for his wit, and then did not raise himself high above the rest of poets." ${ }^{2}$ From Jonson and Dryden we had dramatic as well as Iiterary criticism, for both men lived in a day when the spoken play was extremely popular. In Pope's and Dr. Johnsolls age, Shakespeare's plays were more read than

1. The Great Critics, pp. 213-214

2. Ibid., pp. 291-292 
seen; consequently we notice in the criticism of the period a more purely literary trend. Perhaps Johnson, as Iiterary dictator of the time, is the best oracle to consult for the feeling of the school of classicism. In his Preface (1765) he summarizes his praise of Shakespeare as follows:

This therefore is the praise of Shakespeare, that his drama is the mirrour of life; that he who has mazed his imagination, in following the phantoms which other writers raise up before him, may here be cured of his delirious extasies, by scenes from which a hermit may estimate the transactions of the world, and a confessor predict the progress of the passions.

He defended Shakespeare's violation of the unities and his mingling of tragic and comic scenes; but he made the usual neo-classical charges that the poet's use of conceits, puns, and pompous diction is blameworthy and that "he sacrifices virtue to convenience, and is so much more careful to please than to instruct, that he seems to write without any moral purpose."

Expressed in terms that vary slightly from those of the bulwark of classicism but freighted with the same meaning are the opinions of other eighteenth century editors. Nicholas Rowe, the poet's first biographer, felt that Shakespeare "Iived under a kind of mere light of nature, and had never been made acquainted with the regularity of the written precepts" of Aristotie; Alexander Pope found the poet "not so much an imitator, as

1. Famous Introductions to Shakespeare's Plays, Edited by Warner, Beverley, p. 117

2. Ibid., p. 123

3. Ibid., $\mathrm{p} \cdot 23$ 
an instrument of nature"; ${ }^{1}$ and Lewis Theobald attributed Shakespeare's "offenses against chronology, history, and ancient politicks" not to ignorance but to the "too powerful blaze of his imagination." ?

The late eighteenth century saw the development of a sentimental attitude in Shakespeare criticism, which is still wide-spread. Perhaps Morgann's Essay on Falstaff (1777) may be considered as more or less directly responsible for this point of view. In his study Morgann expressed the paradoxical opinion that Falstaff is no coward, analyzing him as though he were not a character in a book but a real human being. He treated Shakespeare as a supreme and conscious artist, and he philosophized over human nature and aesthetic questions. The germ of the romantic treatment of Hamlet - the topic of Chapter II - was contained in Richardson's explanation (1774) that the tragic delay is due to the moral fineness of the hero, which recoils before the bloody duty laid upon it, and in Mackenzie's and Robertson's modifications of Richardson's interpretations of the character. In Germany the late eighteenth century turned its critical thought toward Shakespeare, and we see at once the natural sympathy between the German and English mind in approaching the poet. The similarity of their criticism at this period may be explained also by the fact that the Germans until

1. Famous Introductions to Shakespeare's Plays, p. 30

2. Ibid., p. 66 
Goethe had no native drama with which to compare Shakespeare, while the English were manifesting a tendency to neglect the circumstances under which the plays were written and their dramatic merit, and to concentrate on the philosophical significance of the characters. In France, on the other hand, Shakespeare could be criticized only by comparison with Cornellle, Racine, and even Moliere. In other words, French criticism was of the theater, while English and German criticism was of the library. Lessing, I believe, was the first German to call attention to the congeniality of Shakespeare to German taste; it is to him, at any rate, that Coleridge attributed the popularizing of Shakespeare in a foreign country. Herder began to appreciate something of poetic pattern in calling attention to the fitness between the passions of the personages and the scenes in which these passions are enacted. The reflective attitude toward poetry was radically influenced by the German critics, particularly Goethe and A. W. Schlegel. We may summarize the trend of this period by quoting Isaacs" statement, "The eighteenth century was an age of Shakespeare idolatry; and the pre-Romantic legacy was an overwhelming belief in Shakespeare's power as the creator of living and plausible characters." 1 Coleridge, then, did not have to invent a new instrument. In the reflective and philosophic studies published

1. A Companion to Shakespeare Studies, Edited by Granvilie-Barker and Harrison, G.B., p. 300 
during the last decade of the eighteenth century he found one that he could adapt to his own use. As Coleridge's Shakespeare criticism is composed largely of an attack on the neo-classical attitude, it will probably be advisable to restate the chief beliefs of the "stop-watch" school concerning the great dramatist. "He wanted art" Ben Jonson had affirmed; and his successors in the Restoration and the eighteenth century had echoed this pronouncement. Their adverse criticism of Shakespeare may be summarized under the following heads:

1. He violates the unities of time, place, and sometimes action.

2. He mingles tragic and comic scenes.

3. He mars his diction by bombast, obscurity, conceits and puns.

4. He ignores the moral purposes of art.

A healthful corrective for neo-classic criticism is found in the great romanticist's psychological and aesthetic study of Hamlet, Lear, Macbeth, Othello, Romeo and Juliet, The Tempest, Love's Labor's Lost, and Richard II; in his essay on Shakespeare's poetry in Biographia Literaria; and in his analysis of Shakespeare's method in The Friend. Coleridge's attitude is expressed in this admonition: "To the young, I would remark that it is always unwise to judge anything by its defects. The first attempt ought to be to discover its excellences." He held up Shakespeare's judgment as a better guide for the poet than 
external rules. "Art cannot exist without nature; and what has man of his own to give to his fellow-men but his own thoughts and feelings, and his observations as far as they are modified by his own thoughts and feelings?"l In his essay on Method in Thought in The Friend (1818) he says, "Speaking of his works, we may define the excellence of their method as consisting in that just proportion, that union and interpenetration of the universal and the particular, which must ever pervade all works of decided genius and true science. For method implies a progressive transition." 2 Again, to prove that shakespeare had his own laws, Coleridge asserts, "He was pursuing two methods at once; besides the psychological method, he had also to attend to the poetical. The latter requires above all. things a preponderance of pleasurable feeling; and where the interest of events and characters and passions is too strong to be continuous without becoming painful, poetical method requires that there should be, what Schlegel calls, 'a musical alleviation' of our sympathy." ${ }^{3}$ Coleridge proves that Shakespeare showed method in his delineation of character, in the display of passion, in his conception of moral being, in his adaptation of language, and in the admirable intertexture of his plots.

The first specific charge of the neo-classicist was that Shakespeare violated the unities. Coleridge's defense lay in what he called the dramatic illusion. Dr.

1. Coleridge, op. cit., I, p. 222

2. Ibid., II, p. 342

3. Ibid., II, p. 348

4. IbId., II, p. 350 
Johnson had destroyed the doctrine of "dramatic delusion", recognizing only the rational and not the imaginative state of the audience. Coleridge replied, "Stage presentations are to produce a sort of temporary half-faith, which the spectator encourages in himself and supports by a voluntary contribution on his own part, because he knows that it is at all times in his power to see the thing as it really is."I This dramatic illusion of Coleridge's will be recognized as intimately related to that "willing suspension of disbelief" which the poet hoped to procure for his contribution to the Iyrical Ballads. According to the critic, reason is aloof from time and space; the imagination has an arbitrary control over both, and if only the poet have such power of exciting our internal emotions as to make us present to the scene in our imagination chiefly, he acquires the right and privilege of using time and space as they exist in the imagination, obedient only to laws by which the imagination acts. "Instead of unity of action, I should prefer homogeneity, proportionateness, and totality of interest," he states in his note on Romeo and Juliet. 2

The second charge of the neo-classicist was that Shakespeare mingles tragic and comic scenes. To this coleridge

1. Coleridge, op. cit., I, p. 200

2. Ibid., I, p. 4 
answers that "Shakespeare imitates life, mingled as we find it with joy and sorrow."l Coleridge is so constituted, however, that he cannot sympathize with the irrelevances of Shakespeare's humor. He asserts, "In no instance can it be justly alleged of him that he introduced his fool merely for the sake of exciting the laughter of his audience." 2 His favorite example of this point is the fool in King Lear. "The contrast of the Fool wonderfully heightens the coloring of some of the most painful situations, where Lear complains to the warring elements of the ingratitude of his daughters." 3 Coleridge's conclusion seemed to be that the comic scenes In Shakespearean tragedy ultimately reinforce the tragic effect by ironical contrast. Dr. Raysor believes that Coleridge's wilful earnestness, the earnestness of a Iyrical romanticist, and his piety toward Shakespeare will not allow him to acknowledge that any of the comedy is for comedy's sake. ${ }^{4}$

The third charge was directed primarily against Shakespeare's use of conceits and puns. Here, too, Coleridge's natural sober-mindedness stood in the way of just criticism. He recognizes the intellectual exuberance which inspired Shakespeare's play on words and states that his use of conceits is natural because of the Elizabethan fashion. He admits, however, that the

1. Coleridge, op. cit. II, p. 212

2. Ibid., II, p. 74

3. Ibid., II, p. 73

4. Ibid., I, pp. xxxv - xxxviI 
historical argument is not sufficient to justify a poet like Shakespeare, who is for all time. The porter's scene from Macbeth he dismisses as obviously not the work of Shakespeare. ${ }^{1}$ He justifies the use of puns as the expression of strong suppressed feeling, as in Hamlet's, "Not so, my lord, I am too much i' the sun." The fourth charge of coarseness and immorality in Shakespeare was to Coleridge the most serious, and combating it was therefore the most congenial task. His defense is admirable in spite of the limitations of his romantic earnestness and the fact that his Shakespeare scholarship was insufficient to enable him to demonstrate how the dramatist had purified the old sources. According to Coleridge, Shakespeare "never clothed vice in the garb of virtue, and the poisonous mists of impurity were never allowed to gather but were driven away by gusts of laughter."2 He justified much that might seem laxness in speech by attributing it to the manners of Shakespeare's age, and he declared that his essential purity was obvious in his treatment of love and in his best women characters. Shakespeare's conception of love was that "The mind of man searches for something which shall add to his perfection, and he also yearns to lend his aid to complete the moral nature of another." ${ }^{3}$ To Coleridge, Shakespeare seemed to possess "all the powers of a man, yet he had all the feeling, the sensibility, the purity, innocence, and

1. Coleridge, op. iit., II, p. 140

2. Ibid., II, p. 266

3. Ibid., II, p. 155 
delicacy of an affectionate Irl of eighteen."I "Shakespeare does not appeal to the appetites but to the passions," he states in summing up his characteristics; he drew women as they are; he has reverence for all professions; he introduces monsters like foneril rarely and then with judgment; and he has great moral wisdom..... There is not a vicious passage in all shakespeare, though many have the grossness of his age; and Shakespeare never forgets his purpose, which was to elevate and instruct." ${ }^{2}$

And so, to his own satisfaction and to the general satisfaction of his period, Coleridge refuted the neoclassical critics' major charges against his idol.

Personal unhappiness turned inward Coleridge's superb analytical powers and forced him to explore his own soul as few men ever have. As a result of his introspection, he was a psychologist of supreme genius with a knowledge of human motives which no other English critic has surpassed. His latest editor, Dr. Thomas Middleton Raysor, states, "In rich ethical reflectiveness, in delicate sensitiveness of poetic imagination, and above all in profound insight into human nature, Coleridge is a critic worthy of his high place at the head of English criticism of Shakespeare." 3 We must remember, however, that Coleridge's primary point of view was literary, not dramatic;

1. Coleridge, op. cit., II, p. 119

2. Ibid., I, p. 229

3. Ibid., I, p. $1 \times i$ 
he often affirmed that he preferred to read shakespeare. His Iimitations in the use of the historical method are apparent. His knowledge, al though wide, was neither accurate nor detailed; he knew Jonson, Massinger, Beaumont and Fletcher, but not Iyly, Creene, Marlowe or Kyd. Then, too, with his heritage of the eighteenth century English and the German idolatry of Shakespeare, he wished to prove the dramatist superior to and distinct rom his age. Consequently, his Shakespeare was a Romantic, not an Elizakethan Shakespeare. T. S. Eliot observes:

When Coleridge released the truth that Shakespeare already in Venus and Adonis and Lucrece gave proof of a most profound, energetic, and philosophic mind, he was perfectly right, if we use these adjectives rightiy; but he supplifed a dangerous stimulant to the more adventurous. 1

If I interpret $M r$. Fliot's comment correctly, the "dangerous stimulant" was the line of approach suggested by Coleridge to the host of critics who have from his day to this sought to study the personality of the dra-matist through his works rather than to study the plays as dramatic art. Upon Coleridge as well as upon the German metaphysicians rests at least part of the responsibility of having made of Shakespeare a philosopher's plaything.

If the space allotted to Coleridge seems out of proportion to that devoted to other critics, I shall excuse

I. A Companion to Shakespeare Studies, p. 298 
the discrepancy by appealing to Professor George Saintsbury, who affirms very simply that of al] the critics the world has yet produced, "Ihere abide these three -Aristotle, Longinus, and Coleridse." ${ }^{1}$

Through Coleridge and the lesser critics of his school, Lamb, Hazlitt, and DeQuincey, the eighteenth century analyzing of Shakespeare's characters as though they were creatures of flesh and blood was passed on to a succeeding generation. With Coleridge originated the study of shakespeare's poetry - a study which is still in its infancy - and a subjectivity of approach which may have been responsible for much of the sentiment in the criticism of the later nineteenth century. "The Romantic legacy to posterity was an insistence upon Shakespeare as a creative and original genius, whose contribution was to be measured and traced," according to Isaacs. ${ }^{2}$ Before we examine the ways in which the succeeding generation attempted this measuring and tracing, we must call attention to vordsworth's acknowledgment of the German superiority in recognizing that the "judgment of Shakespeare in the selection of his materials and in the manner in which he made them constitute a unity of their own and contribute all to one great end is not less admirable than his imagination, his invention, and his intuitive knowledge of human nature." 3 Doubtless

I. Saintsbury, George, History of Criticism, III, p. 230 2. A Companion to Shake speare studies, p. 300

3. Ibid., p. 304 
Wordsworth is not to be questioned. With the temerity of the mateur, however, I might suggest that all that Wordsworth found in the German critics, I found also in Coleridge.

Let us look at the ways in which the later nineteenth century used its legacy from the Romantic critics. Along with sentiment, there arose investigation into the statistics of Shakespeare's versification and the exact measurement of his poetic processes. The critic employed his genius as an excuse for studies as wide as character analysis, creative unity, periodizing, verse processes, chronology, and the poet's personality. Now we see moving alons side by side two trends in shakespeare criticism, the scientific or objective and the romantic, philosophical, or subjective. Partly because we are approachins so near to our own day that it is difficult to get the proper perspective, and partly because the lines of study are so varied, it is now no longer possible for me to select one critic as typical of a particular movement. I can only point out those who seem especially interesting in the history of shakespeare criticism. From a long list I have chosen men with a firm claim to literary and critical distinction, like A. C. Bradey; writers typical of a trend, like Dowden and Masson; and Shakespearean scholars, like schucking and Stoll, whose theories are too well propounded and too well documented to be ignored.

In Germany Ulrici and Cervinus, approachins their task philosophically, built a shakespeare whose pattern 
of growth could be traced in well-marked successive periods. David Masson attempted in 1865 to reconstruct the personality of Shakespeare throuch his works. "Disconnect our Impressions of remarkable poems ..... from our knowledge of their authors, or our desire for knowledge of them" he said, "and our Literary Criticism, our whole theory of Literature, degenerates into dilettantism." I From the scant facts of the recorded life of the poet and the comments of his contemporaries and from the plays themselves, liasson bullt up a complete biography of Shakespeare with which he seemed quite satisfied. Realizing the meagerness of actual data, Masson stressed the value of the plays as the source of information concerning the poet's moral views, his philosophy of life, and his mode of thinking. "Imagination," he contended, "is not creation out of nothing, but recombination, at the bidding of moods and of conscious purposes, out of the materials furnished by memory, reading, and experience. The so-called creations of a poet, therefore, belons to him, and do, in however subtle a way, reveal himself." ${ }^{2}$ Masson was the first critic to elaborate the study of the poet's moods, stressing particularly the final mood of reconciliation manifested in whe Tempest. "It is best in the main," he thought, "to read Shakespeare with nothing intervening between one's own intelligence and the plain, clear, printed text." 3

1. Masson, David, Shakespeare Personally, p. 16

2. Ibid., 130

3. Ibid., pp. $237-238$ 
Like Ulrici, Gervinus, and Masson, Dowden also attempted to trace Shakespeare's growth and succeeded in giving the first unified and rounded picture of the whole achievement of the dramatist. Dowden, like Masson, is somewhat looked down upon by the modern realistic critic because of a sentimental attitude that sometimes borders on gushing. Brandes and Frank Harris also belonged to this school of personality builders. I have already mentioned the fact that a scientific criticism was being developed in the latter half of the nineteenth century, with $\mathrm{R}$. Q. Moulton's Shakespeare as a Dramatic Artist as the outstandins contribution. In A. C. Bradley's Shakespearean Tragedy, I see for the first time a felicitous combination of a subjective critical tendency and a recognition of the necessity of scientific analysis. Bradley's object was "to increase an understanding and enjoyment of the plays as dramas; to learn to apprehend the action and some of the personaces of each with a greater truth and intensity, so that they assume in our minds a shape a little less unlike that which they wore to Shakespeare." He advised reading a play as if one were an actor who had to study all the parts. ${ }^{I}$ With his emphasis on dramatic rather than literary appreciation, Bradley anticipated the more modern critics, schucking and Stoll. Although he stressed as the prime requisite for such appreciation an intense and vivid imagination,

I. Bradley, op. cit., pp. I-2 
he pointed out also the necessity of comparing, analyzing, and dissecting. Only through a combination of the imaginative and analytical faculties, Bradley felt, could we arrive at genuine appreciation.

With the close of the nineteenth century we see the waning of philosophical idealism and the waxing of the new realism in criticism. The shelves of any well-stocked library will present an appalling array of contemporary critics; but as the purpose of this chapter is to mark the outstanding feature of each age, I have selected from the multitude the German, I. I. Schucking, and the Americans, Elmer Idgar Stoll and William W. Lawrence, who have turned to the evidences of the plays and, above all, of contemporary dramatic conventions for the proof of their theses. These men have tried to display not a modern Shakespeare, a Victorian Shakespeare, or a Romantic Shakespeare, but the Elizabethan Shakespeare. They have held. steadily to this purpose, and they have resisted all temptations to use the dramatist as a springboard for plunges into philosophy, history or ethics. Because of their tenacity of purpose and their vigor of presentation, the three chosen will perhaps make a more immediate impression upon the reader than would less vehemently partisan realists of undeniable acumen, like Raleish, Quiller-Couch, Shaw, Robertson, Santayana, Caroline Spurgeon, G. B. Harrison, and John Dover Wilson - all of whom will appear in Chapter III. 
Schucring has presented the theory that a judicjous interpretation of Shakespeare's characters will have to start, not with the action, but with the questions: "What do the characters say about themselves?" and "That do others in the play say about them?" In other words, soliloquies are to be taken at face value, and remarks made by one character about another are to be believed. He also states that Shakespeare chose popular plots, borrowing those that drew in another theater, that collaboration was cormon and anonymity customary when he came to Iondon, and that his anachronisms were deliberate and flarant bids for popularity with the audience he never forfot. Professor schucking's theories proceed from the valid assumption that shakespeare was a true child of his own century, the avatar of the Realissance spirit, quick with love and hate, subject to comon moods and passions, caring more for the market plece than the cloister, and writins more for his ase than for all time.

Stoll believes that an uncerstanding of shakespeare's plays may be sained only throuch seein: them as they appeared to the lizabethan avdience. In his shakespeare Studies, he attacks the autobiographical fallacy of Masson's school of thought by showing that Shakespeare's periods were periods of creation rather than of experience. In refutine the "final mood of reconciliation" 
theory, he states that Shakespeare's Iater plays ended happily, not because he had climbed out of the depths on to the heights, but because the romantic comedy had returned to favor. lot only Shakespeare's but also Massinger's and Beaunont and letcher's plays ended happily auring this period. ${ }^{1}$ In the same book he riddIes Morgann's attitude toward the character of Falstaff, stressins the impropriety of psychoanalyzing literary 2

characters; and he proves that shylock is to be accepted as a comic figure. constantly stoll reminds us that Shakespeare wrote as an actor, a manager, and a maker of stage plays, which were not regarded as literature. He wrote to please himself and his audience; no one coula have regarded his readers less, for he expected none. He wrote only for the immediate effect, and he employed an art whjch he had learned, not out of books, in the schools, or from the ancients, but on the stage and in the pit and the gallery.

Lawrence ${ }^{4}$ stresses the importance of a study of medieval literature and life for an understanding of Shakespeare's plays; therefore, in attemptin; to solve the definite problems presented by Shalrespeare's darker comedies, he presents their historical and social groundwork. The points to be remembered in connection with the problem comedies are that they were designed for

I. Stoll, Bliner E., Shakespeare Studies, pp. $84-85$

2. Ibid., p. 124

3. $\overline{\text { Ibid. }}, \mathrm{p} \cdot 27$

4. Lawrence, Milliam 7.7 Shakespeare's Problem Comedies 
entertainment; that comedy was tuming more and more to realism, often gross and drastic, to study of character based upon contemporary types, and to a serious, questioning, and sometimes satirical view of life; that the reaction against the artificialities and sentimentalities of romance brought its own exaggerations; that the "melancholy" hero was a popular type; and that plays of sexual intrigue pleased Shakespeare's later public. Perhaps Iawrence's rethod in dealing with the "problems" in tre individual comedies can be presented more pointedly through his analysis of the wager in Cymbeline. Posthumus, it will be rememberod, Save a villain an opportunity to seduce his wife in order to prove her chastity. Iawrence shows how this episode, so unsavory to the modern taste, is in accordance with sizabethan 1deals. First, the old theme fits the spirit of sixteenth century chivalry; and second, Posthumus' fantastic conduct is the only course possible for the perfect knight and lover, for it is thus that he proves his implicit confidence in his wife's virtue.

In this survey I have tried to illustrate the main currents in Shakespeare criticism. We have seen the dramatic criticism of Zen Jonson and Dryden succeeded by the neo-classical literary criticism of Dr. Johnson; the origin of Shakespeare idolatry in the eighteenth century with the sentimental criticism of Richardson and Irorgann; the discovery of Shakespeare by the Cerman phizosophers and. 
metaphysicians at the end of the same century; the subjective, psycholouical analysis of Coleridge and other Romantic critics; the simultaneous development of a scientific and an autobiographical criticism in the latter part of the nineteenth century; and the rise of a purely objective criticism through the historical and comparative methods of contemporary realists. In other words, we have seen the philosophers and psychologists remove Shakespeare from the stage to their own studies where they developed a purely aesthetic criticism. Now we are witnessine an attempt on the part of the critic to restore the playwright to the clobe or the Eankside where we can understand him only through a reconstruction of the Blizabethan dramatists, and the manners and morals of the period. Wuch of the background necessary for sich a view of Shakespeare's work has been supplied by Joseph Quincy Adains in his Shakespearean Playhouses; Thomas Whitfield Baldwin in The Organization and Personnel of The Shakespearian Company, Sir Arthur Quiller-Couch in Notes on Shakespeare's Workmanship; and $G$. B. Harrison in Shakespeare under Elizabeth. In spite of the flourishine state of realistic criticism, romantic criticism, that natural outgrowth of an idealistic philosophy, we still have with us. But we shall allow the modern romantic critic to speak for himself in Chapter IV on a subject that has always been nearest his heart - the play of Hamlet. 


\section{CHAPTER II}

THE ORIGIN AND DEVELOPNENT OF THE EARLY RONANTIC CRTTICISA

$$
\text { OF FAMLET } \quad(1784-1900)
$$


THE ORIOIN AND DEVELOPMENT OF TIE EARLY ROMANTIC CRITICISM OF HAMLET - 1784 to 1900

With the necessary equipment of some understanding of the whole field of Shakespeare criticism, we may now examine the Hamlet criticism in detail. I repeat, "the necessary equipment," for the character analyses which in the last quarter of the eighteenth century began to supersede criticism of plot were a direct reaction against neo-classical criticism and a direct reflection of a change in the conception of the function of literature. For the present chapter, in which I shall point to the orifin and trace the development of the romantic attitude towards the character of Hamlet, I have purposely crouped those critics who busied themselves with Hamlet as if he were a real person rather than a fictitious character. I shall confine my examination to the central mystery of the drama: Why does Hamlet delay in fulfilling his promise to the Ghost to avenge his "foul and most unnatural murder"?

In limiting the scope of my study in this fashion, I am guided by the realization that, in spite of scattered comments concerning other questions of plot and other characters, the major interest of the nineteenth century critic was with those qualities of mind and spirit which prevented Hamlet's carrying out his vow to the murdered majesty of Denmark. The reader will be prepared then for psychological 
and aesthetic criticism, for the criticism of the study rather than of the theater. Such philosophical commentators as Coleridge, Lamb, and Hazlitt, for example, stated very frankly that they did not like to see their author's plays acted, and least of all Hamlet. It seemed to them that no other play suffered so much in being transferred to the stage, for what actor's art was sublime enough to depict their favorite hero? Under the spell of Shakespeare's power of characterization they seem to have forgotten entirely that this Hamlet, whom they analyzed as though he were the most complex of human beings, was the poet's puppet, with life and breath only for the duration of the play. They speculated about man and Nature, about God and Fate, about Truth and Beauty; and their reader, expecting to wade pleasantly in the shallows of dramatic criticism often finds himself swimming in a metaphysical sea.

In the whole field of Hamlet criticism two camps coexist with regard to the character of tre hero: the first holas that fianlet is shakespeare's study of the impractical temperament, his portrait of a dreamer; the second, that Hamlet is possessed of extraordinary courage and promptness.

Let us return to our question: Why does Hamlet delay in fulfilling his promise to the chost to avenge his "foul and most unnatural murder"? From the answers the

1. Raleigh, Walter, Shakespeare, p. 198 
romantic critics make to this query, eight types of Hamlet eventually emerge, six of them in the first camp and two in the second.

The first Hamlet to apnear - the morally fine hero whose nature recoiled before the bloody duty - is endowed with all the "sensibility" of his creators, Richardson, Nackenzie, and Robertson.

"His amiable hesitation and reluctant scruples," declared Richardson, who made the first significant study of the character, "Iead him at one time to incecision; and then betray him by the self-condemning consciousness of such apparent imbecility, into acts of rash and inconsiderate violence. Harnlet and persons of his constitution contending with less virtuous opponents, can have little hope of success." He felt that, although the character of Hamlet inspired almost reverent love and grief for his sufferings, at the same time his weaknesses, amiable thongh they were, were the cause of his disappointment and early 1 death.

Although Fenry Wackenzie followed Richardson closely, he showed Hamlet also as the victim of extreme sensibility, which plunged him into melancholy and deprived him of energy. "We feel the weaknesses as well as the virtues of Hamlet as our own," wrote riackenzie. "We see a man, who in other circumstances would have exercised all the moral and social virtues, placed in a situation in which

1. Variorum Shakespeare, Edited by Furness, Horace Howard, $\mathrm{IV}, \mathrm{p} \cdot 15 \mathrm{I}$ 
even the amiable qualities of his mind serve but to aggravate his distress and to perplex his conduct." I

'These two men and Fobertson, who attributed Hamlet's fatal delay to gentleness, anticipated Goethe and coleridge in emphasizing the weakness of the character.

The second Hamlet is the idealist confronted by a problem to which he is not equal. He is the Hamlet of the metaphysicians, Coethe, Ferder, Courdaveaux, and Ten Brink.

According to the great German critic and dramatist, Goethe, Shakespeare sought to depict a great deed laid upon a soul incapable of performing it.

Here is an oak tree planted in a costly vase, which should have received into its bosom only lovely flowers; the roots spread out, the vase is shivered to pieces .... A beautiful, pure, and most moral nature, without the strength of nerve which makes the hero, sinks beneath a burden which it can neither bear nor throw off.

(oethe's Hamlet resarded every duty as holy, but the obligation imposed upon him by the chost he found too hard. The impossible was required of him - not the impossible in itself, but the impossible to him. So, coethe continued, "he winds, turns, agonizes, advances, and recoils, ever reminding himself, and at last almost loses his purpose from his thoughts, without ever again recovering his peace of mind." To Goethe Iamlet seened endowed more properly

I. Variorum Shakespeare, IV, p. 148

2. Ibia., p. 273 
with sentiment than with a character. He saw him pushed on by events alone to his tragic end, with Fate drawing the plan. ${ }^{1}$

foethe's contemporary, Herder, had explained Hamlet's procrastination as the result, not of base cowardice, but of a metaphysical and conscientious scruple; ${ }^{2}$ and the French critic, Courdaveaux, thought that Hamlet was held back from actins by the secret volce of conscience and the shrinkins of a delicate soul from an assassination in cold blood. "It is a horritle obligation," he said, "for which he is not made. The honesty of his conscience, the instincts of his nature, the habits of his education revolt afalnst it." In his conception of Hamlet, Courdaveaux felt that shairespeare volced his own sadness and weariness of life. 3

Only five years before the close of the nineteenth century, Bernhard Ten Brink stated that since Coethe's Wilhelm Meister we had not penetrated much further into Hanlet's character. More than one hundred years of probing, all to no avail! Surely the spirit of coleridge stirred when Ten Erink made that solemn asseveration. "The deeds of the hero of tragedy which are the cause of his sufferings constitute the tragic error." According to Ten Brink, Shakespeare gave us in Eamlet an idealist who, placed amid surroundines incongruous with his nature,

I. Variorum Shakespeare, IV, p. 273

2. Ibid., p. 277

3. Ibid., p. 388 
saw himself confronted with a problem to which he was not equal and which proved his ruin. "Hamlet's character and Shakespeare's real intention remain a mystery. "ye never see Hamlet truly confront his task. As in the other great tragedies, we see a soul alone in the universe."I The third Hamlet, like the second, is an idealist; but circumstances embitter him to the injury of his noble nature. This is the Prince presented by G.G. Gervinus and Paul Stapfer.

Gervinus felt that Hamlet was unequal to the real world; and, repelled by it, he not only lamented its deficiencies but grew cynical and sickly about it. In his bitterness of feeling he seemed to cervinus a type of the German race of the critic's own generation. "The story of Hamlet is the degeneration of a moral nature," according to the rrench critic stapfer. Through the fault of circumstances and also the lack of a just balance of qualities, a man of great talents and virtues underwent intellectual trouile and moral degeneration. Neither weak nor irresolute, he possessed the finest inborn moral sense; but meditation conquered him, and he accepted any excuse against action. Abundant thoushts that led nowhere produced physical and noral impotence. 1. Ten Brink, Bernhard, Five Lectures on Shakespeare, 2. Variorum Shakespeare, IV, p. 299 3. Ralli, Augustus, $\frac{\text { A History of Shakespearian Criticism, }}{\text { II, pp. } 64-65}$ 
The fourth Hamlet is the morbidly reflective and speculative hero. Call him A. A. Schlegel's or Coleridge's Hamlet; he is also the Hamlet of Hazlitt, Vischer, Turck, Kreysig, Dowden, Feis, and Lanier.

A. W. Schlecel pointed to what he saw as Hanlet's own analysis of his difficulty:

Thus conscience doth make cowards of us all. And thus the native hue of resolution

Is sicklied o'er with the pale cast of thought. III, i, $33-85$

"In the resolutions which he so often embraces and never carries out, his weakness of will is evident. He is a hypocrite towards himself," accused schlegel. "Hamlet has no firm belief elther in himself or anything else .... (In his story) the destiny of humanity is exhibited as a gigantic sphinx, which threatens to precipitate into the abyss of skepticism him who cannot solve the enigma."I

"In Hamlet," Coleridge believed, "the balance between attention to outward objects and our meditation on inward thoughts, the balance between the real and the imasinary world, does not exist. Hence his enormous intellectual activity and his consequent aversion to real action, with all its symptoms and accompanying qualities." When we hear coleridge remarkine that an aversion to action is natural to the temperament of the man who has a world in himself, we are immediately reminded that on another occasion he declared that he himself had a smack of Famlet 
in his nature. And when he presents his theory that through the play Shakespeare wished to impress on us the truth that action is the chief end of existence, we remember that tragic "Ay de mi" of Coleridge's own, Work without Hope. According to Coleridge, Shakespeare created his characters out of his own intellectual and moral faculties, by conceivine any one intellectual or moral faculity in morbid excess and then placing himself, thus mutilated and diseased, under the given circumstances. The intellectual faculty which was developed to morbid excess was Hamlet's "craven scruple of thinkins too precisely. on the event;" and it was this tragic flaw that caused his failure. Turn to the soliloquy of Act II, scene 2, "O, what a rogue and peasant slave am I," this critic directed, and note the lines

Yet I -

A dull and muddy-mettled rascal, peak, Iike John-a-dreams, unpregnant of my cause.

When move to that of Act IV, scene 4, "How all occasions do inform against me," and re-read

Now, whether it be

Bestial oblivion, or some craven scruple of thinkine too precisely on the event,A thought wich, quarterid, hath but one part wisdom And ever three parts cowara, I do not know Why yet I live to say, "This thing's to do," Sith I have cause and will and strength and means To do't.

These two passaces, according to Coleridge, are Hamlet's character, self-attested. ${ }^{2}$ Coleridge felt that free will

1. Coleridge, op.cit., I, p. 37

2. Ibid., I, p. 20 
was the first cause in tragic drama and that accidents were never introduced. To cause the death of the hero by an accident would be beneath the tragic muse, as the catastrophe would arise from no mental action. Hamlet's conflict, then, was with internal rather than with external forces.

In the opinion of Hazlitt, Hanlet, the prince of philosophical speculators, deliberately declined his revenge because he could not have it perfect, according to the most refined idea his wish could form. His ruling passion was to think, not to act; and any vague pretext that flattered this propensity instantly diverted him from his previous purposes. Although his character was marked by refinement of thought and sentiment, Hamlet seemed to Hazlitt as little of the hero as a man could well be. He saw him as "a young and princely novice, full of high enthusiasm and quick sensibility - the sport of circumstances, questioning with fortune and refining on his own feelings, and forced from the natural bias of his disposition by the strangeness of his situation."2 Hazlitt understood the universal appeal of the character better than his Ereater contemporary, Coleridge. Coleridge saw himself in the Prince; but Hazlitt knew that Hamlet is Everyman. "Hamlet is a name," he wrote; "his speech and sayings

1. Coleridge, op. cit., I, p. 278

2. Hazlitt, William, Lectures on the Iiterature of the Age of Elizabeth and the Characters of Shakespeare's Plays, pp. $76-78$ 
but the idle coinage of the poet's brain. What then, are they not real? They are as real as our own thoughts. Their reality is in the reader's mind. It is we who are Hamlet."I

To Kreysig and Vischer, also, Hamlet's procrastination seemed due to an excess of a reflective, meditative habit of mind. "The horrible harvest of death in the fifth act shows that aimless weakness, even though clad in the finest Garb of intellectual keenness, spreads around far more inisery than the most inconsiderate violence," observed Kreysig. 2

"Phinking alone never leads to action," Vischer stated succinctly. "rhought seeks an absolutely fit moment, and in Hamlet there is none." Although his task was not insuperable, it was difficult to perform because the imaginative mind falters at the thought of a practical deed. The mental triumph of unmasking the Kine, and the moral and intellectual satisfaction that attended the unmasking sufficed him. To the melancholy Prince it seemed hardy worth while to slay Claudius, for how could one man punish the wickedness of the world? ${ }^{3}$ This idea was repeated later by both Turck and Brandes.

Professor Dowden described. Hamlet as a man to whom persistent action, particularly the duty of deliverate hevenge, was peculiarly antipathetic. "Under the pitiless burden imposed upon him, Hamlet trembles, totters, falls.". Made for honesty, he wascompelied to use the weapons of 
his adversaties, and thus he wasted himself in ingenuity and crafty device. In the corruption that surrounded him, he was tempted to understand and detest, not to accomplish some limited practical service. In spite of difficulties without and within, Hamlet clung to his terrible duty. He was not incapable of vigorous action, if he were allowed no chance of thinkine the fact away into an idea. "Does Iamlet finally attain deliverance from his disease of the w111?" Dowden asked; ${ }^{2}$ but $I$ do not think he found an answer to his own question.

Ignoring the historical side of the play and the influence on Hamlet's mind of his father's death and his mother's remarriage, Jacob Feis contended that Shakespeare wrote Hamlet to refute the philosophy of llontaigne, which the dramatist considered a dangerous influence because it disturbed the mind without clearing it and thus produced despair. Hanlet, who represented nontaigne, liked hunanistic studies but also adhered to old dogmas. His sou]. struggle arose from a divided mind - the fact that he found "nothing either good or bad." Iike nontaigne, he was preoccupied with the thought of death; but this obsession arose from superstitious christianity rather than from the free use of reason. To Shakespeare the French writer who allowed himself to be driven about by his feelings seemed

1. Dowden, Edward, Shakespeare:His Mind and Art, pp. 115-116 2. Ibid., p. 130 
to need an object lesson. To teach that we owe everything great in the world to the full and free use of reason, he created Hamlet, a philosopher with energy paralyzed by thinkine too much and arriving at no decision.

"From the beginning to the end, Hamlet never really makes up his mind. He is morally an interrogation point," the poet Lanier felt. He answers life's questions by asking another question: Ought I to do this or that? Shall I believe the Ghost or doubt him? Shall I stab the King or not stab him? Shall I be insane or shall I not be insane? Ought I to avoid this dreadful mission of setting right a disjointed time, or accept it? "Thus the real thrusts at Iramlet, and Hamlet thrusts not back but leaps aside. Perhaps Famlet's absolute lack of belief, combined with his yearning belief that he does believe, has never been properly insisted on." Hamlet alleges that he does not kill claudius because of a perfectly clear conviction as to what will happen to the King after death, a point which a moment before he said no man could determine. When Eamlet talks about heaven and hell here, he is saying, "And I, Hamlet, believe that I believe this, and so I will not take this opportunity for revenge." The key to his character is that half-belief which does not know that it believes, but only believes that it believes,

1. Ralli, op.cit., pp. 8-9 
"and so twists its belief from moment to moment to suit its mood, and hence a thousand inconsistencies." ${ }^{1}$

The fifth Hamlet - the fatalist who in his ceaseless dreamine has lost sight of the finite and sees only the infinite - is the Hamlet of Victor Fugo.

"IIe believes himself to be no more the master of his fate than is a sparrow. It is on this passive creature that the mission has devolved of overthrowing a tyrant. Hamlet looks on himself as powerless. Shakespeare has made him a fatalist avenger!" said Euro. Again we are plunged into a metaphysical sea by this critic's observation that the struggle between Will and Fate belons not only to the history of Iamlet but to the history of all mankind.2

The sixth Hamlet is a poor moral weakling who made a practice of neglecting his duties. Richard crant White slipped this Ijamlet in amons the more sympathetic portraits, neglecting to state by what law of literature or of life he should be accepted as the hero of serious tragedy.

Although Hamlet wished to assume his rightful position in the kingdom, white stated, he had not the steady selfassertion and daring necessary for thrusting another down who stood in his place however wrongfully. Tis was "one of those natures into which wrong enters like a thorn to wound and rankle, not as a spur to rouse endeavor." sorely

I. Lanier, Sidney, Shakespeare and His Forerunners, pp. 264-267 2. Variorum Shakespeare, IV, p. 390 
smitten in his two tenderest points, his ambition and his love for his mother, he was capable of nothine but weak despair and dejection of soul. This mood was the natural result of his constant neglect of the active duties of his position, and his habit of watching and ponderine the conduct of all around him. His weariness of life came from too much observation and reflection. When he refused to. kill Claudius lest he send his soul to Heaven, he only pretended to deceive himself with this argument. All he really wished was to shuffle away from and procrastinate what he felt to be his solemn duty. "Poor moral weakling! His thoucht and his intent were always the straws of every gust of accident." I

Iet us cross over to the second camp. The seventh Hamlet, in strikins contrast to the others so far presented, is a brave and resolute man whose nature rebelled at performing an action which was not the result of his own judgment. Hermann olrici described this independent spirit. The Prince possessed courage, energy, will, and resolution, declared irici, but because his will was guided by judgment, he was slow to act. By nature a philosophical spirit, he had both the desire and the power to accomplish great things. Any action on his part, however, had to be "in obedience to the dictates of his own thought and

1.White, Richard crant, Studies in Shakespeare, pp. $80-94$ 
by his own independent, original, and creative energy." We behold in Hamlet, Urici said, "the Christian strugGling with the natural man. The natural man spurs him on to immediate action and charges his doubts with cowardice and irresolution; the Christian spirit draws him back, though still resisting. He hesitates between the two in an attempt to preserve his own liberty of will and action." ${ }^{1}$ The eighth and last Hamlet to be considered here is the victim of an inexorable fate, swept on to inexpljcable destruction. This is the senecan hero of Cunliffe, Traumann, wendell and Swinburne.

Victor Hugo had painted a hero who failed because of his negative philosophy, but the critics who described the eighth Hamlet found fatalism in the plot rather than in the character. They interpreted the play as the climax of the reflective tendency in shakespeare and in the English drama, though coupled, as in Seneca, with a full complement "of carnal, bloody, and unnatural acts." According to J. W. cunliffe, the fatalism in the play was of the hopeless Stoic kind which included the gods themselves.

If it be now, 'tis not to come; if it be not to come, it will be now; if it be not now, yet it will cone; the readiness is all.

$$
\mathrm{V} \text {, ii, 224-227 }
$$

lot liamlet, but the hand of chance brought about the catastrophe.

2. Variorum Shakespeare, IV, pp. $292-293$
Cunliffe, J.W., The Influence of Seneca on Lizabe- 
To Barrett wendell the play taught that men are the sports of a tragic fate, the storm, passionate, Christianized fate of Romantic Europe.

Thought, emotion, conduct, life in all its aspects are alike at the mercy of this unspeakable force, yet these very men, whirled onward though they be towards the portals of pternity, must think, must feel, must act, must live.

To others and even to themselves they must seem the responsible masters of their destinies. Hendell felt that Iamlet voiced Shakespeare's passionate, restless aclnowledgment of this unfathomable mystery.

innest rraumann also showed us a hero who defied fate and who preferred to succurb rather than to sacrifice his most intimate self and his nobility of spirit. Defrauded of his innermost earthly happiness, and cut off from his age, country, and surroundings, he fell back upon himself and his own mind until eventually will was extinguished by thought. Hamlet could have reached the goal of revenge had it been merely revenge he was seeking. It was no tangible object for which he foucht; it was his own spirit. 3

The point at which Swinburne left the other critics in this group was in his verdict that Hamlet was not overirresolute. At times, he pointed out, the hero acted with almost unscrupulous resolution. To refute the popular theory with recard to the character, he attacked the wisdom

\footnotetext{
1. Wendell, Barrett, Wiliam Shakespeare - A Study in

2. Itid. Eizabethan Iiterature, p. 259

3. Ralli, op.cit., pp. 112-115
} 
and the common sense of taking the soliloquies at their face value. From those speeches alone the majority of commentators had built up their wan-visaged prince whose "native hue of resolution" was "sicklied o'er with the. pale cast of thought." Because this opinion differea so essentially from the commonly accepted one that through the monoloeves only could we arrive at a true estimate of Iamlet's character, I shall let swinburne speak for himself:

A man whose natural temptation was to swerve, whose inborn inclination was to shrink and skulk aside from duty and from action, would hardiy be the first and last person to suspect his own weakness, the one only unbiased judge and witness of sufficiently sharp-sichted candor and accuracy to estimate aricht his poyerty of nature and the malformation of his mind.

So startinely modern is the swinburne who drew this portrait of Iamlet in 1889 - such a veritable white blackbird - that we find Professor Stoll, whose custom it is to agree with no man, actually quotine him more than half a century later. ${ }^{2}$

- With the eight pictures before us, let us inquire into the accuracy of Ten Prink's statement regarding the lack of proceress made by the nineteenth century critics towards the understanding of Ianlet's character. All oÍ these critics regarded the play merely as a frame to set off the hero. All but four, cunliffe, Iranmann, wendell, and Swinburne, found the motivation of the tragedy in the 1. Swinburne, Alsernon charles, A Study of Shakespeare 2. Stoll, Elmer E., Art and Artifice in Shakespeare, 
nature of the hero. Take the idealist confronted by a problem to which he is not equal and endow him with a "craven scruple of thinking too precisely on the event"; and in the oethe-Schlegel-coleridge compound which results will be found the Hamlet that deliwhted the aesthetic fancy of the nineteenth century romantic critic. Professor Ten Prink was richt! 
CHAPTER III

THE REAITSTS' HAMLET (1866-1936) 
While the romantic critics of the late nineteenth century were still following the Goothe tradition, the new spirit of realism was keginning to manifest itself in Iamlet criticism. The critics considered in this chapter, all approachine their problem objectively, have recognized the existence of the delay in the plot. Accordin to their analyses, the old story upon which the play is based, not the character of Hamlet, is responsible for that delay. Shakespeare's task was to revise a tragedy of blood; and although he could not tamper with the basic episodes of the drama, he could and did make a hero to suit himself.

In 1866 Gustav fumelin ripped through the fabric of the popular nineteenth century theory by reminding the reader that shakespeare found the delay in the old story he was revising. What dramatist, strivin to please his audience, would have had the temerity to change or suppress the main outlines of a popular and well known story? Such a playwright would have met with as certain failure as the story teller in whose version of Bluebeard none of the wives was murdered.

1. Variorum Shake speare, I., pp. 324-328 
To Rumelin's consideration of the nature and limitations of Shakespeare's materials of plot, we may trace the rise of the historical-comparative method of the objective school of critics. Briefly summarized Rumelin's contentions were as follows:

1. Shakespeare retold an olc story.

2. The character of Hamlet was incongruous with that story.

3. Therefore, the work as a whole was imperfect.

No important critic has since forgotten the first statement, and only one, T.S. Eliot, has since agreed with the third. The crux of criticism, then, is still the character of Hamlet - not the flesh and blood hero of the romanticist, but the fictitious character in relation to the incidents of the plot.

Here a digression from criticism proper seems necessary, for, with the late nineteenth century fervor for history, the realistic critic concerned himself with such questions as where Shakespeare found his material and how he transmuted it, and with analyses of the three main forms in which the play of Hamlet is extant. ${ }^{I}$

Let us return to Shakespeare's workshop to look at Iamlet in the making. Saxo Crammaticus' story of Amlethus, which appeared in Latin in his Historia Danica from 11801208, reached England through the medium of Belleforest's

1. The great body of textual criticism, which is one of the important developments of the historical method, is not relevant to the present study. 
French translation, Histoires Trasiques, in 1570. This book in turn was rendered into English as The Mistorie of Hamblet probably in 1608, after the publication of the second Quarto. In the Amleth saga as in Shakespeare's play, we have the murder of the father by the jealous uncle; the mother's marriage with the murderer; the son's feigned madness; the vague originals of Ophelia and Polonius; the meeting of mother and son; and the voyage to England. The orisinal Fanlet zoes to England without interruption from pirates, witnesses the death of his two companions, and returns and kills not only the king but all his courtiers. The elements of the plot which are not found in the old story are the chost, the play-scene, and the death of the hero as well as the objects of his revenge. Whese belong to the Elizabethan drama.

The theme was familiar on the English stage apparently by 1589 when it seems to be alluded to by Thomas Nashe in his preface to Freene! s Henaphon:

Yet English seneca read by candlelight yeeläes many good sentences, as Bloud is a beggar, and so forth; and if you intreate him faire in a frosty morning, he will affoord you whole Hamlets, I should say handfulls of tragicall speeches.2

In 1594 Henslowe's Diary records a play called Iianlet as acted at Newington Butts Theater on June 9 . In 1596 Lodge's Wits liserie and the World's lladness, we read, "Fe looks as pale as the ghost which cried so miserably at the

I. Gollancz, Israel, the Sources of Harlet, p. 85

2. Murray, Gilbert, Hanlet andorestes, pp. 4-5 
theator like an oyster-wife, Hamlet, revenge." In 1598 Cabriel Harvey mentioned Shakespeare's Eamlet.

Hamlet, then, like most of the great Elizabethan plays, presents itself to us as a whole that has been gradually built up, not as a single definitive creation made by one man in one effort. All evidence points to the existence of an old play as early as 1587, perhaps by Kyd; and before Hamlet was an Inglish play, it was a Scandinavian story. Had then Shakespeare no orisinal power? the reader may be asking at this point.

The originality of Shakespeare was threefold:

1. He transformed and upraised other men's crude creations.

2. He put admirably imagined characters and admirably turned speech where others had put unplausible puppets and unreal rhetoric.

3. He rose from the monotonous blank verse of his predecessors to "a species of rhythm as inherently great as that of iliton at his most skillful, and more nervously powerful, because more dramatic.

Into the old tragedy of blood that his Ilizabethan audience knew and loved, he infused the magnificence of his poetry, the amazing subtlety of his psychology, and the intensity of the tragic emotion.

Shakespeare's first revision of the lost play of Kyd must have been made in 1601; and although it could not have been thorough, it was adequate to attain sensational popularity. Immediately Jons on touched up The Spanish

1. Murray, Gilbert, op.cit., pp. 4-5

2. Robertson, J.M., Montaigne and Shakespeare, 0.265 
Tragedy for the Admiral's lien, and Marston wrote Antonio's Revenge. In fact, the Hamlet of 1601 started a vogue in tragedies of revenge. Anthony scoloker wrote, "Faith, it should pleese all, like Hamlet;" and the Chamberlain's men were called on to present the play before the two universities of Cambridge and oxford. This General acclalm made Hamlet a desirable item to the publishers. Usually there was only one complete copy of a play, the original manuscript bearing the official license of the censor. The playhouse copyist gave each actor his own part, which he was expected to keep under lock and key. Evidently the corrupt text issued in 1603, the First Quarto, was printed from a manuscript concocted from notes taken at the theater, possibly with the assistance of the written parts of one or two hirelings in the chamberlain's Company. I The play of Hamlet is extant in three main forms: the First and Second Quartos and the First Folio.

1. The First Quarto, the stolen and corrupt text dated 1603 but perhaps printed in 1602, was entitled "The Tragicall Historie of Hamlet Prince of Denmark by William Shake-speare, As it hath been at divers times acted by his Highnesse servants in the Cittie of Iondon: As also in the two Universities of Cambridge and Oxford and elsewhere." This edition has only 2,143 lines, many of them incomplete, as against the 3,891 lines of the Globe edition.

1. Adams, Joseph Quincy, $\frac{\text { A Life of William Shakespeare, }}{\mathrm{p} \cdot 306}$ 
It differs from our version also in the order of the scenes and to some extent in the plot. For instance, the Queen's innocence of her husband's murder is made quite explicit. When she hears how it was wrought, she exclaims,

But, as I have a soul, I swear by Heaven

I never knew of this most horrible murder.

and thereafter she acts confidentially with Hamlet and Horatio. Some of the names also are different: for Polonius, we have Corambis; and for Reynaldo, liontano. 2. The Second Quarto, dated 1604, described itself as "enlarged to almoste as much againe as it was, accordinc to the true and perfecte coppie."

3. The Eolio of 1623 differs in a very large number of details from that of the second Quarto; and it contains some 85 Iines not in the Quarto, while the Quarto has about 218 lines not in the Folio. Both of these sets. of omissions appear to be due to cuts made for acting purposes. It is clear that these two texts were printed from independent copies of the althor's manuscript; and most, if not all, of the variations in detail may be accounted for by the carelessness of transcribers and printers. They are not such as to prove an aditional revision by the dramatist.

The excursion into the history of the play concluded, we may return to the realistic critics, who portray five types of Hamlet. 
Four of these types appear in the camp of the critics who think Iamlet a dreamer; the fifth, in the camp of those who think him a man of action.

The first Famlet is Shakespeare's attempt to depict a sensitive, senerous, and reflective nature, with which the delay imposed by the old plot would not be incongruous. rhis was Rumelin's theory, and it is echoed with slight variations in the criticism of Brandes, Shaw, Raleigh, Quiller-Couch, Robertson, Santayana, Caroline Spurgeon, and others.

Rumelin was the first critic whom I found deliberateIy ignoring the character of Hamlet in discussing the cause of the delay, and pointine out the necessity of retarding movements in a tragedy. In other words, Rumelin began again to consider the plot as of more importance than the hero. Had Hamlet executed the act of vengeance immediately after the appearance of the chost, he argued, the drama would have ended with the second scene. Hamlet acted throughout, and his self-reproaches showed how filled he was with the thought of his task. In adaptine an old legend, Fumelin declared, Shakespeare kept the main outlines of the plot, but let the hero represent his own disgust and disillusionment. This irreconcilable discrepancy between the vehicle and the character made him consider the play one of the dranatist's most imperfect works. The Hamlet to whom Shakespeare gave the tender sensibility, 
the melancholy, the spirit, and the wit of his own soul was no longer fit to be a Northern hero, the bloody avenger of a bloody deed. Rumelin did not claim that his theory cleared away the difficulties and obscurities in the plot, but he felt that it at least explained how the incongruities between the nature of the hero and the nature of his deeds had arisen. ${ }^{1}$

Instead of deploring the discrepancy between the old story and Shakespeare's hero as Rumelin had done, the Danish critic, ceorge Brandes ${ }^{2}$, saw an advantage in the incongruity of a Hamlet who believed in the chost and yet doubted him, who accepted the summons to vengeance and yet delayed. The dramatist introduced a Renaissance hero in the medieval fable. Hamlet suddenly realized that everythine was entirely different from what he had imagined, and he felt as if he must die because he could not set it right. Findins it difficult to believe the world so bad and seeking for proof, he planned the play. ITe was not in the main incapable of action, but he had a great inward obstacle to overcome. Reflection hindered him. (Irandes reminded us here that the technique of the play required a hero who did not act). His faculties paralyzed by his new realization of what life is, he brooded over how little would be gained by gettine rid of a single noxious

I. Variorum Shake speare, IV, pp. 324-328

2. Brandes, George, dilizam Shakespeare, pp. 366-370 
animal. "To Hamlet, life is half reality and half drean," Brandes concluded. "His melancholy was the result of his indicnation. Evil was too strong, too cunning for him."I

The Hamlet corge Pernard Shaw would like to see on the stage is a man in whom the common personal passions are superseded by wider and rarer interests. The critical self-consciousness of such a person males the practical efficiency of the instinctive man on the lower plane impossible to him. Te finds the duties dictated by conventional revence and ambition as disagreeable a burden as commerce is to a poet. Indeed there is a sense in which Shaw's Hamlet is insane, for "he trips over the mistake which lies on the threshold of intellectual self-consciousness: that of bringing life to utilitarian or Hedonistic tests, thus treatine it as a means instead of an end. ${ }^{2}$

Walter Raleigh's Hamlet is not unlike Shaw's. The weakness of Famlet, he felt, lies in the fact that he cannot concentrate for any leneth of time on a narrow, practical problem. He cannot "reruse himself that sudden appeal to universal considerations which is called philoșophy or humor." Sensitive, thoughtful, generous, and impulsive as he is, he cannot escape his fate. Shakespeare "watched his heroes, awe-struck, as he saw them

1. Brandes, ceorge, op.cit., p. 370

2. Shaw, Eorge Bernard, Dramatic opinions and Lssays, 
drawn into the eulf", and he felt that "what they suffer is out of all proportion to what they are." They are presented with a choice, and the essence of the tragedy is that choice is impossible. Hamlet fluctuates between thought which leads nowhere and action which is narrow and unsatisfying. Raleigh found a curiously business-like vein of criticism running through the essays and remarks on Hamlet, with their talk of failure and success. Apropos of those critics who think Hanlet's delay was justified. by his desire to do his duty in a more effective and workmanlike fashion, he said, "The melancholy Prince has certainly not been able to infect all who read his story with his own habit of thought." A play is not a collection of biographies, he reminded us, but the grouping of certain facts and events around a single center so that they may be seen at a slance. Hamlet's mind is that center. "It is not by what he does that he appeals to us, but by what he sees and feels." Action and contemplation, which the dramatist usually separates by embodying them in different persons, are not separated in the character of Hanlet. His actions surprise himself. "His reason, beine Shakespeare's reason, is superb in its outlook and sits unmoved above the strife." 1

"I suggest that all these critics have been pluckins: different hearts out of the mystery and exhibiting them, I. Raleigh, op.cit., pp. 134-202 
simply because there was never any mystery in Hamlet, and consequently no secret heart to pluck out," Sir Arthur Quilier-Couch maintained, ${ }^{I}$ and he supported his arçument with three proofs:

I. It is never the test of the highest art that it is unintelligible.

2. Hamlet is the most popular of Shakespeare's plays. 3. Every actor wants to play Hamlet, and when he comes to it, he always plays it successfully.

Shakespeare, of course, invites each of us to put himself in Hamlet's place. "The point of every tracedy is its demand on our several assent - Irhere, but for the grace of cod, go I' ..... Cannot any one of us, imagining such a shock to fall upon hin as fell upon Hamlet, conceive it as rocking his mind in violent oscillation on its pivot?" Quilier-Couch asked. 2 Famlet was never thrown of the pivot, although his own mind occasionally suspected that he had been. As for his delay, Hamlet was a man of sentle, scrupulous nature and of an exceedingly active intellect; and all the positive evidence he had was the word of the chost. His responsibility was to his own conscience. "Ihat is why, being a frown and thoughtful man, he coula not strike as the nineteenth century commentators demanded. He was scrupulous. That is why (as he told us) he designed the play-scene. That is why (as he

1. Quiller-Couch, Arthur, Shakespeare's Worlmanship, 2. Ibid., p. 165 
told. us) he could not kill claudius "pat" while he was praying . Hamlet himself at times was moved by a doubt of the Ghost's authenticity. "Why should such a man as Hamlet not shrink from the deed and cast about for a new incentive? The charge is imposed upon him. He loathes it. At first he finds thought of it so intolerajle that he contemplates suicide." I

No charge of delay can be brought against Hamlet except between Acts I and II, avows J. M. Robertson, and to stab a man in the back would hardly produce a high moral or aesthetic effect. Shakespeare has supplied the critics with grounds for accusing Hamlet of delay through the hero's self-reproachine soliloquies. Jamlet, however, is neither weak nor outmatched by circumstances. The author should have explained the hero's delay; but as he did not, Robertson explains it for him. Critics point to Ophelia's speech, "Nay, 'tis twice two months, my lord," to prove that two months have elapsed since the appearance of the chost. Shakespeare, takine up and rewriting Iryd's already modified play and not finding the simple explanation originally fiven there that Hamlet was prevented from prompt action by the presence of the suards, now dropped from the play in conformance with Enclish court practice - accepted a mysterious delay where none had been planned and created a new psychological 3 situation.

1. Quiller-Couch, op. cit., pp. 171-172

2. Robertson, J. The Problem of Hamlet, pp. 16-27

3. Robertson, J. M, The State of Shakespeare Study, p. 33 
Kyd's trasic method was one of lone baffled action, and the devices which Shakespeare used for delayinc the outcome were his machinery in adapting a barbaric story in which a barbarian had to delay because he was the only one agrainst a powerful chief. The pessimism, which proceeds from Famlet's sickness of heart and which makes us feel that revenge is no remedy, is shakespeare's personal contribution; but much matter which conflicts with that pessimism, such as the hero's displays of sudden vigor, remains. I In the ldeal Hamlet, Shakespeare saw a princely spirit vibrating under his torture, and through his own pain doubly alive to all the beauty and tragedy of the world. "The events of the play were there, and he had to accept them; and in this acceptance, Shakespeare revealed his great idiosyncrasy. ${ }^{2}$

Ceorge Santayana states his beljef concerning the material of great poetry thus:

Imagination needs a soil in history, tradition, or human institution, else its random growths are not significant enough and, like trivial melodies, go immediately out of fashion. A sreat poem needs to be built up and remodeled on some Given foundation with materials already at hand."

Shakespeare followed a classic precept in the romantic drama; he allowed the plot to suggest the characters, and he conceived their natures and psychological movement only as an underpinning and satiric deepening for their known

1. Robertson, J. M., The Problem of Hamlet, pp. 66-74

2. Ralli, op.cit., II, p. 447

3. Santayana, George, obiter scripta, p. 41 
actions. Survivas of cruder methods give a touch of incoherence to Hamlet's character, otherwise sufficiently complex, according to santayana. His reasons for sparing Claudius are a remnant of the bombast belongine to the old story. In famlet's personality incoherent sentiments, due, in a genetic sense, to the imperfect recastine of a erotesque old story, are made attributable ideally to his habit of acting out a mood irresponsibly and of giving a mock expression to every successive intuition. Thus his false rhetoric before the prayin Claudius becomes characteristic and may be taken to betray an inveterate vacillation which seizes on verbal excuses and plays with unreal sentiments in order to put off the moment of acting. Hamlet's mind possessed infinite sensibility but no mastery over itself nor over thinss. Shakespeare fell in love with his hero. He caught in the figure of Famlet, at first only grotesque and melodramatic, the suggestion of something noble. He developed that suggestion and at the same time elaborated the story, even constructins a youns Hamlet to stand behind the play. The old problem of Hamlet's delay Santayana answers by reminding the reader that the play pre-exists and imposes itself on the poet, who is reduced to pavins the way as best he can for foregone complications. Hamlet is irrational. He acts without reflection, as he reflects without acting. At the basis of all his ingenuity

I. Santayana, op.cit., pp. 42-67 
lies this piece of inexplicable folly, that he conceals his discovery and postpones his revenge. This unreason is a sort of passionate weakness and indirection in his will, which works its own ends.

It is the tragedy of a soul buzzing in the Glass prison of a world which it can neither escape nor understand, in which it flutters about without direction, without clear hope, and-yet with many a keen pang, many a dire ima inary problem, and much exquisite music. 1

The theme of the play is a hidden crime met by a fantastic and incapable virtue. There is no richer or more exquisite monument to the failure of emotional good will, and of intelli ence inclined to embroider rather than to build.

Caroline spurgeon arrives at her interpretation of Shakespeare and indirectly at her understanding of the individual plays through her study of the poet's inages. In Hamlet she points out images of sickness and disease or blemish of the body and she discovers the idea of a tumor the dominating one as descriptive of the unwholesome moral condition of Denmark. Hamlet speaks of his mother's sin as a blister on the "fair forehead of an innocent love"; Certrude speaks of her "sick soul"; heaven's face is "thought-sick" at the act; Claudius is a "mildew'd ear" blasting his wholesome brother. This state of corruption which shocks, paralyzes, and finally overwhelms Hamlet is the foul tumor breaking inwardly and poisoning the whole body, while showing

1. Santayana, op.cit., p. 52 . 
.... no cause without

Why the man dies.

$$
\text { IV, iv, } 28
$$

According to Dr. Spurgeon, when the play opens, Hamlet

has already begun to die internally. She says:

Shakespeare sees Hamlet's problem not predominantly that of will and reason. 'He sees it pictorlally not as the problem of an individual at all, but as a condition for which the individual himself is apparently not responsible, any more than the sick man is to blame for the infection which strikes and devours him, but which nevertheless in its course and development, impartially and relentlessly annihilates him and others, innocent and guilty alike. That is the tragedy of Hamlet, as it is perhaps the chief tragic mystery of life.I

A Hamlet who cannot act but can only feel, reflect, and plan is described by John Jay Chapman; 2 one whose mind is ill at ease in a detestable society, by W. Macneile Dixon; 3 and a hero whose delay is due to his mind and heart, by Raymond ilacdonald Alcen."

The second Ifamlet of the realists is the morbid and melancholy "type" popular in Elizabethan drama. He is described by Corbin, Eilbert murray, Lillian instanley, Schucking, and . E. Harrison.

There are two contradictory phases in Hamlet, stated John corbin, the first critic to bring before us the temper of an Elizabethan audience. One is a remnant of the hero of Kyd's Spanish Iragedy, Hieronimo; the other, a foreshadowing of the character that is to come. In

\footnotetext{
1. Spurgeon, Caroline, $\frac{\text { Shakespeare's Tmagery and What }}{\text { It Tells Us, pp.318-319. }}$

2. Chapman, John Jay, A Clance Toward Shakespeare, pp. 34-42

3. Dixon, W. Macneile, Tracedy, pp. 102-103

4. Ralli, op.cit., II, p. 432

5. Ibid., p. 117
} 
many plays, from haste or policy, Shakespeare left whole episodes that savor of the cruder aspects of Elizabethan draina. He was a popular dramatist, who knew that insanity amused the playcoers. To them Hamlet's feigned madness seemed comic in some scenes which are trafic to the modern mind. In the pre-shakespearean story there was no real insanity, but remodeled by Shakespeare, Flamlet's mind became acute, sensitive, and morbid under the strain. In plot Hamlet went back to the lost play, in which action was deferred. The shakespearean element was concerned with his reflective, imaginative, humane traits. The character of Hamlet, like that of orestes, is a traditional type, Professor ilbert Inuray ${ }^{l}$ told the Britisi Academy in 1914. From the interaction of the two elements of tradition and invention, or the conscious and the unconscious, the story of Hamlet had been built up by many minds in many generations. In all versions the dramatic character of the play had required that the hero should be under the shadow of madness. There is that in the character of orestes which makes it easy for him to $80 \mathrm{mad}$. Of Shakespeare's hero Murray said, "In Hamlet, the madness is assumed, but I trust I am safe in sayin there is somethine in the hero's character which at least makes one wonder if it is entirely assumed." 1. Murray, Gilbert, op.cit., pp. 4-10 
In a fit of exasperation John Drinlrwater once said that nine tenths of what Shakespeare wrote is as plain as pike-staff, and that the critics concern themselves with the one tonth that is obscure. Quilier-couch is of the opinion that nine tenths of all that has been written on Hamlet is rubbish. Neither of these eminent creative artists, however, could refrain from adding his drop to the sea of criticism. Quiller-Gouch's ire was evidently aroused by such studies as Edward P. Vinting's demonstration in The Iystery of Hamlet that Hamlet was a woman and in love with Horatio; and an anonymous author's proof In an article in the popular Science Ronthly of liay, 1860, "The Impediment of Adipose - A Celebrated Case," that the key to Hamlet's delay is found in certrude's observation, "He's fat and scant of breath" !

I am not suggesting that Miss Iillian Winstanley's Hamlet and the Scottish Succession belongs to the nine tenths of critical rubbish; but it does seem to carry the historical method to a dangerous extreme. Fhe author compares the play with the Amleth story on the one side and the historical details on the other, and proves to her own satisfaction that the main problems of the play are those of the history rather then those of the saga. liss instanley's brief is as follows:

Realizin the interest of his audience in the question of the scottish succession and the wssex. 
conspiracy, Shakespeare set about dramatizing this story and the character of James $I$. Fe took the plint of James, whose father, Darnley, had been murdered and whose mother, Mary, married his father's murderer, Pothwell. The prince was acclaimed the avenger of his father. The situation had only one flaw - the prince was an infant and coulc not pursue vengeance. shakespeare overcame this defect by combining the two Bothwells, using the action of the elder and the character of the youner. Ihe central situation was the situation of Janes; the central proulem, the vacillatin; will of a man who knows he ought to act but cannot act, was the proliem of Janes' charucter. Whe hatred of bloodshed, the love of milosophic discussion, with interest in spirits and the night side of nature, the love of disputation, the wittiness, the feignin of stupidity which sonetimes made him suspected of madness, the carelessness of dress, the hebit of swearin, the use of tablets - all these were James' characteriatics. rihe play of Ilanlet, then, was lancely an appeal to the interest of the Elizabethan audience in their future king. As they witnessed the arama, Shakespeare planned that they should wish to take Eamlet - James out of his uncongenial Denmark - Scotland and introduce him to a nobler sphere. Hamlet was not solely a portrait of James I; he contained much of Essex as he was in the last years of his life. Essex, who had a deeply studious side 
to his nature, was startlingly like Famlet in his latter days, irresolute almost to the point of insanity, surrounded by cunnin enemies who plotted against his life, and haunted by a premonition of disaster. Hamlet could not live, as Lsex could not live, to "hear the news from Ensland," but he prophesied that the "election" would light on Fortinbras - James and save him his "dying voice." Fortinbras commanded that Hamlet - Essex's body be placed "on a stase" and that full honors be paid him. James did acknowlede his debt to Essex, for he restored his family to title and honors and set free his followers. According to iss instanley, then, Hamlet's character is a composite of James I and the Jarl of issex in his later years; and his delay is a composite of James I's chronic vacillation and the requirements of the Amleth saga.

The psychological stuaies of Famlet's character were almost unanimous in interpreting his reasoning in the soliloquy which begins

How might I do it pat, now he is prayine, And now I'II do't - And so be coes to reaven,. III, iii, $72-73$

as an excuse for further delay. "It must be made a principle," the cerman critic schucking says, "to deny that shakespeare makes any character in a monologue state reasons for his actions that are not meant to be 1. Winstanley, Li]lian, $\frac{\text { Hamlet and the Scottish Succession, }}{\text { pp. } 89-163}$ 
substantially correct and sufficient." "What Famlet regards as terrible in his father's death is his lack of preparation. In his desire to kill the King whon he is about some evil deed, he proves himself a severe, even a cruel avenger. Had the reasons stated been merely specious ones, Shakespeare would have made Hamlet say so. If we have noted Flamlet's hesitancy to act, if we have seen him shrinkin from the deed without reason, we must remember that when shakespeare uses an old story, he elaborates and refines the character of the hero, but he retains the action. In the lost play of Iryd's, which Shakespeare revised, Hamlet did not kill the Kine at this point; and too much tampering with a story as popular as this must have been to warrant Shakespeare's usine it, would have displeased the audience. Schucking believes that "the less complicated and more natural the solution of the difficulties we attempt, the more we endeavor to make the given ideas suffice for the explanation, the fewer the unexpressed ideas we introduce, the greater is the probability that we shall hit upon the correct meaning - the meanins intended by shakespeare himself. "2 When Shakespeare wrote Iamlet, the "melancholy type" was almost a fashionable ficure; and although the great dramatist had the power of creating individuals rather than types, the audience knew their melancholy man as soon as he stepped out on the stage. 
His inky cloak, his downcast eyes, his windy sighs, his inability to act systematically, his escape from reality to reverie - all these were his hall marks. Schucking advises the actor never to lose sight of the neurotic condition of Harlet, but to adopt an air of beinc languid and exhausted by lack of sleep, morbid, inwardly restless, irritable, and intolerant. ${ }^{1}$

Even though Shakespeare revised the olc play, it was still a play of revenge, accoraing to $t_{t}$. B. Harrison, 2 and there was an etiquette to be observed. In The Spanish Tragedy, the plot was divided into three actions: how Horatio was murdered; how Fieronimo discovered the murderer; and finally how he took adequate and artistic revenge. The playgoers expected the victim to pay fuller measure than he gave in this world and to perish everlastingly in the next, being cut off at the moment when there would be no opportunity for him to make peace with Divine Providence, so that damnation could be satisfactorily insured. Kyd stressed. the infernal aspect of venceance, opening his play with the appearance of the ghost of Don Andrea and of Revenge herself, who at the close withdraws to drag off her victims to Tartarus:

For here, though death hath end their miseries, I'll there begin their endiess Irasedy. ${ }^{3}$.

Hamlet planned "the mousetrap" to make sure of the Ghost's honesty, for he had every reason to suspect that

1. Schucking, op.c1t., pp. 160-164

2. Harrison, B., Shakespeare Under Elizabeth,

3. Chief Elizabethan Dramatists, Edited by Neilson, Wm. Alden, p. I84, II. 44-47 
he might be a devil or the kind of illusion common in the advanced stages of melancholy. When he had proved the King's guilt, he spared him because he was praying. He wished to take his uncle

At gaming, swearing, or about some act That has no relish of salvation in't. III, iii, $91-92$

In the delay, then, Shakespeare was merely following the pattern of the revenge drama.

The third Hanlet- the Hamlet of T. S. Eliot-is the victim of hís own disgust.

In The Sacred Wood, Eliot expresses the opinion that "so far from being Shakespeare's masterpiece, Hamlet is most certainly an artistic failure." It is a play dealing with the effect of a mother's guilt upon her son, and "Shakespeare was unable to impose this motive successfully upon the intractable material of the old play." Hamlet is full of some stuff that the writer could not drag to lisht, contemplate, or manipulate into art. "Famlet (the man) is dominated by an emotion which is inexpressible, because it is in excess of the facts as they appear." Although his disgust is occasioned by his mother, she is not an adequate equivalent for it; and it envelops and exceeds her. Because his disgust is a feelin which he cannot understand or objectify, it poisons his life and obstructs action. "None of the possible actions can

1. Eliot, T.S., The Sacred Wood, pp. 98-101 
satisfy it; and nothing shakespeare can do with the plot can express Hamlet for him." The dramatist simply tackled a problem which proved too much for him. "Why he attempted it at all is an insoluble puzzle; under compulsion of what experience he attempted to express the inexpressibly horrible, we cannot ever know."

A fourth Hamlet emerges from Lily Campbell's study of Shakespeare's Tragic Heroes - the slave of passion, a figure easily comprehensible to the philosophy of shakespeare's day.

Miss Campbell advanced the theory ${ }^{1}$ that in his tragedies Shakespeare was concerned with passion rather than with action. Read against the background of contemporary philosophy, Hamlet comes to lif'e for her as a study in passions, obviously constructed to show the profound truth of its dominant idea:

$$
\begin{aligned}
& \text { What to ourselves in passion we propose } \\
& \text { The passion ending doth the purpose lose. } \\
& \text { The violence of either grief or joy } \\
& \text { Their own enactures with themselves destroy. } \\
& \text { Where joy most revels, grief doth most lament; } \\
& \text { Crief joys, joy grieves, on slender accident. } \\
& \text { III, ii, } 204-209
\end{aligned}
$$

Shakespeare's method was to show people of different temperaments under the influence of the same passion so that we may see the passion variously manifested. For this purpose he employed Hamlet, Fortinbras, and Iaertes. The

I. Campbell, Iily B., Shakespeare's Tragic Heroes, 
fundamental problem of the play is the way in which men accept sorrow. In Fortinbras, grief is dominated by reason, whereas in Laertes and Hamlet, we see excessive grief leading to destruction. Laertes' passion, not to be consoled or appeased, turns to anger; and Hamlet's dulls and effaces his memory until he is guilty of the sin of sloth.

"To philosophers of Hamlet's day, the picture of one moved to revenge by heaven and hell and yet stayed by excess of grief from action, of one impelled by passion to revenge and yet through excess of passion having the cause of passion blurred in his memory, would not have seemed to call for poetic exposition."I Hamlet's type of grief was one generally accepted in his day, and in the play the Elizabethan audience read shakespeare's challenge of philosophy to passion. The result for Hamlet was devastation, while Fortinbras and Horatio, the two characters in whom reason had swayed passion, lived to dominate the scene.

\footnotetext{
.....blest are those Whose blood and judgment are so well commingled, That they are not a pipe for Fortune's finger Io sound what stop she please. III, ii, 73-76
}

That is the lesson of the play.

I. CampbeII, op.cit., p. 132 
The fifth Hamlet takes us into the second camp. In striking contrast to the other four, he is a hero possessed of extraordinary courage and promptness, a practical man who acts throuchout the play. He appears in the analyses of Werder, Norgan, Brander latthews, Wucker, Stoll, and Dover Wilson.

A very starting theory in its day was that put forward by Karl werder. 'Whether or not Hamlet could do what the critics seemed to expect is irrelevant, Werder thought. He did not dare to do it, for entirely objective reasons. Suppose he had killed the King and had taken the throne. What then? He would have had only the Ghost's story as a reason to give the people; and he alone, the only man in Denmark personally interested, had received the message. What then was Famlet's iminediate duty? "Ivot to crush the King at once - but to bring him to confession, to unmask and convict him." Killing the King before he had confessed would be, not killing the guilty, but killing the proof. "Jpon the one side, a welldeveloped fortress, and without, a single man, who is to take it, he alone. So stands famlet confronting his task!"

A manly, punctilious, rational farnlet, suspicious of intuitions, deliberately perseverins, and unwilins to base action on supernatural testimony is described by Appleton Morgan. There was no blunted purpose in the

I. Variorum Shakespeare, IV, pp. 354-371 
soul of this truly English prince, for whom a vendetta had no time limit. He merely waited to satisfy himself.

Hamlet is not obscure on the stage, states Brander Matthews, and he knows what he wants to do. Were he weak of will, the spectators would long since have lost interest in one who does not know his own mind. In the play we see the eternal trasedy of the human soul at war with inexorable circumstances, not passively submissive 2 to them.

Although he alligns himself definitely with the objective critics, William John Tucker ${ }^{3}$ accuses them of failine to explain the real cause of the conflict between Hamlet's lower and higher nature. The Prince's relicion has taught him that a purgatorial spirit cannot incite to crime. The Ghost had made three injunctions:

1. Revenge my foul and most unnatural murder.

2. Taint not thy mind.

3. Nor let thy soul contrive against thy mother aught. As the rightful heir to the throne of Denmark, Hamlet must act, not in a personal and vindictive manner, but as an instrument of justice, vindicating the violated rights of family, of religion, and of state, The courts of justice are closed against him by the murderer who holds absolute sway. Hanlet's plan, therefore, is to secure 1. Norgan, Appleton, Shakespeare in Fact and in Criticism, 2. Matthews, Brander, Development of the Drama, p. 213 3. Tucker, Wm. John, Collese Shakespeare, pp. 195-198 
undeniable proofs of Claudius' guit, not to put uforea court, but after claudius' death, to offer to the people as justification of the act. The play shows clearly that he kills the Kinc only after he has secured such proofs. The reasons Hamlet gives for sparing the King at prayer cannot be construed as his real sentiments, since they are in contradiction to his Christian principles. They are simply the expression of the fierce hatred which has momentarily taken possession of his lower nature. The real consideration that stays his hand is his realization that by killing the rine now he would be disobeying the Ghost's command as well as destroying all possible proofs of his uncle's secret crime. "Hamlet fails to strike the Kine at prayer, not from 'paralysis of will power' but from a self-restraint dictated by prudence and conscience, which is only another way of sayine that he possesses an exceptionally strong will." According to this critic, other objective studies have not paid sufficient attention to the undeniable fact that famlet does hesitate to act throus subjective causes, until claudius has betrayed his guilt and proved the veracity of the Ghost. From the moment that his perfectly rational doubts are satisfied - during the Hurder of Gonzago - his delay is due to external causes. "Hamlet's story," Professor Tucker concludes, "Is a history of purposes adhered to and of an end which compassed them." I

1. Tucker, Wm. John, op. Git., p.198 
Mr. Logan Pearsall Smith's "hard boiled" critic, Elmer Edgar Stoll, believes that he has found the formula of Shakespeare's tragedies. ${ }^{I}$ The hero is put into a plight which requires conduct to which his nature is superior and to which he is averse. This situation is brought about by external means; and the improbabilities are allayed by the reality of characterization, the interest of a quickly moving story, the veiled confusion of motive, and the all reconciling power of poetry. Shakespeare had to use the essentials of Kyd's story; in other words, he had to begin with the chost and end with the tragic deed. In the interim Hamlet must busy himself secretly with intrigue and melancholy meditations and publicly with a pretense of madness. The dramatist could malre slight changes in the story, of course, but none so drastic as the introduction of a procrastinating, weak-willed hero. If critics have taught us to see Famlet in such a licht because of his self-reproaches in the soliloquies, Stoll reminds us that these self-accusations were a tradition of the stage, that Hamlet is spoken well of by others, and that he is capable of intrepid activity on many occasions. In the soliloquy which begins, "O, what a rogue and peasant slave an I," the hero reproaches himself with his failure to do anythine but feign madness and baffle hostile curiosity.

1. Stoll, Elmer E., Art and Artifice in Shakespeare, 
In the second, "How all occasions do inform against me," he reproaches himself with his failure to do anything but confirm the ghost's report. These self-charges arise naturally and are needed to satisfy the audience that the hero is about his business. If Hamlet had possessed the defect that the critics suppose, Shakespeare could not have allowed it to drop out of the play as he does; for there is no hesitancy about the hero's actions in the latter part of the drama. The Plizabethan audience understood the devious movement of the revenge play and knew that in the old story claudius was not killed until the end. After both soliloquies there is action, and that is what the pit and the gallery saw. Thus the author was able to content his patrons, to shield his hero, and to prolon the play. The Elizabethan playgoer delighted in intrigue, circuitous but cunnins, bloody but pootically just, and took it for what sha lrespeare intended it to be, a story, not of Hamlet's procrastination, but of the prolonged and artful struggle between him and the King. Famlet's disdain of confidants and confederates adds to his dignity and pathos, and his reticence about his plan serves to keep the audience in suspense. If he produces no definite scheme toward the end, he gains immeasurably by letting the King take the lead and load his own soul with the whole burden of the final slaughter. Stoll says of this Hamlet he portrays: 
Whatever may be thought of him, such an heroic but pathetic Hamlet as I have presented has the advantage over the morbid one of being stage-fit and fairly intelligible, which the psycholosist has never made him, and of being in keeping with the text, the time, and the dramatic fradition and theatrical favor of two centuries.

Since 1917, John Dover Wilson has been engaged in an eager pursuit of clues to the central problem of Hamlet. This pursuit has led him through his two volumes of textual criticiam, The Iis. of Shakespeare's Hamlet and the Problem of Its pransmission, and his edition of the play in Ihe INew Shakespeare series to his solution of the mystery in his latest book, that Happens in Iamlet. What Fappens in Hamlet is concerned only with the dramatic effectiveness of the play. The drama was. written for Ilizabethans by an Elizabethan, Professor wilson reminds us. If we of the twentieth century wish to enter fully into the situation, we must ask ourselves how it would present itself to English minds at the end of the sixteenth. Hanlet is an English prince, the court of Elsinore is modeled upon the English court, and the Danish constitution is that of England under Elizabeth. Therefore to the Blizabethan audience, Hamlet was the rightful heir to the throne and Claudius a usurper. The usurpation is one of the main factors in the plot, and it is vital that we moderns should not lose sight of it. In short, Hamlet's ambitious designs, or what his uncle so construes, form a leading element 
in the relations between the two men throuchout the play. Ilamlet is a tragedy of genius causht fast in the toils of circumstance and unable to fling free. So overwhelming is the moral shock of his mother's guilt that it shatters all his zest for life and all his belief in it. Opon the bowed figure of this Prince, the chost lays one more load, the task. The second command, "taint not thy mind," comes too late, for Hamlet's mind is already tainted. The thost wishes Certrude saved from Claudius, but if Hamlet should let the courtiers know of the King's guilt, they would suspect the Queen as his accomplice. To Harnlet's other burdens we have added his doubt of the chost. At the end of Act I, the hero, together with the audience, is left in doubt as to the "honesty" of the spirit. So great is Hamlet's moral stature, so tough his nerve, that his back does not break under the weight; but he is crippled, and his arm is paralyzed. His strenth enables him to bear the burden but not to discharge it. He assumes madness because he is conscious that he no longer retains perfect control over himself, and the "antic disposition" enables him to conceal his nervous breakdown. If the play proved the chost honest, Hamlet intended to finish claudius off immediately, but the King's crime must be kopt secret for the salvation of Gertrude and the family honor of Denmark. Fis "mousetrap" catches both King and court, for while the 
former interprets The Inurder of Gonzago as evidence that Hamlet knows all, the latter draws the deduction that Iucianus is Hamlet threatenine the usurper with death. Hamlet returns from his voyage to England a changed man, with an air of self-possession greater than at any other time of the play. The requirements of tragic drama compel his creator to win back our respect for him before the end. He is now the complete Prince, dignified, cool, reflective, very noble in his speech to Laertes before the match, and still nobler in his death. His duty now performed, he no longer fears what draans may come when we have shuffled off this mortal coil.

With the five Hamlets of the objective critics before us - the generous and reflective hero, the melancholy "type", the victim of his own disgust, the slave of passion, and the man of action - we are in a position to examine what the realistic interpretation of Fanlet has added to the romantic towards a more adequate understanding of the play. All of the critics quoted in this chapter have recosnized the fact that shakespeare used an old plot which dictated that the elder Hamlet's murderer could not be punished until the end of the play. The nineteenth century romanticist asked, "Why did Eamlet delay?" acceptine the Prince as a person capable of determining the outcome of 1. Wilson, John Dover, What Happens in Hamlet 
the plot. The realist asks, "What manner of hero has Shakespeare created to perform the deeds a familiar story narrates?"

In attempting to answer that question, he has studied the sources of Shakespeare's plot, the traditions of his theater, medieval and Iizabethan philosophy, and the psychology of the Elizabethan playgoer, to whom the play was "the thing" of primary importance. Stressing the fact that Shakespeare was a popular dramatist, whose purpose was always to please his public, the historical critic has given the twentieth century romanticist a firm foundation for his creative criticism. 
CIJAPTER IV

THE TWEITIEIH CENTURY ROMANTICISTS ' HAMTET 
Wany twentieth century critics are frankly subjective in their approach to the play of Iamlet. Seldom concerning themselves with answering or attacking the position of the objective group, they write their aesthetic and impressionistic commentaries to suit themselves. Their acceptance of the discoveries of the historical critic, however, sets them apart from the nineteenth century romanticist.

They are a heterogeneous company, these subjective critics. They cone from the university lecture room, the poet's study, the philosopher's library, the actormanager's theater, even the psychoanalyst's clinic to tell how they interpret Ilamlet. Again the play is a frame for the portrait of the hero, not the chief concern as it is with the objective critic. Into that frame they fit eight pictures of Jamlet, the dreamer in seven poses, and the man of action in one.

First we find a Hanlet who saw too great issues everywhere to play the trivial same of life. He is the Hamlet of Yeats, Masefield, Tree, Trank Wa thews, Chambers, and Logan Pearsall Smith.

At Stratford-on-Avon in 1901, William Butler Yeats, Irish dramatist and poet, wrote his impressions of the 
Danish Prince. Hamlet failed, Yeats believes, because he could not regard life as important. He and all the court acclaimed as the only befitting Kine, Fortinbras, who came from fighting battles about "a little patch of ground" so poor that one of his captains would not give "six ducats" to "farm it." Hamlet's deeds had no obvious use; they were indeed no more than the expression of his personality. That is why it was thought that shakespeare was accusing him and telling us to be careful lest we deserve the like accusation. It did not occur to the critics that you cannot know a man from his actions because you cannot watch him in every kind of circumstance, and that a man is made useless to the state as often by abundance as by emptiness, and that a man's business may at times be revelation and not reformation. Fortinbras was, it is likely enough, a better kins than Hamlet would have been; but, after all, was not he "who changed nothing for the better and many things for the worse greater in the Divine fierarchies? ${ }^{1}$ John Masefield, English poet laureate, writes, "Hamlet is the tragedy of a man and an action continually baffled by wisdom." The man is too wise. The dual action, pressing in both cases to complete an event, cannot get past his wisdom into the world. The action in one case is a bad one; it is simply murder. In the other it is revenge, or taking blood for blood. In the shakespearean scheme 
It is not revenge, it is justice, and therefore neither Sood nor bad but necessary. The situation which causes the tragedy is one very common in shakespeare's system. Iife has been wrenched from her course. irenching is necessary to bring her back to her course or to keep her where she is. Hamlet is a man who understands too humanly to wish to wrench either this way or that and too shrewdy to be himself wrenched by the grosser instruments of sate. "The action consists in the baffling of action. All trrough the play, there is the uneasiness of somethin trying to get into life, but baffled always because the instrument chosen is himself a little outside life, as the wise must be." This baffline of the purpose of the dead leads to a baffling of the living, and at last to something like an arrest of life, a deadlock. The world in wich Famlet must act is Governed by the enemies of intellect, by the sensual and worldIy, by deadly sinners and materialistic philosophers. Although the task set by the rhost is a simple one, to the delicate and complex mind so much of life is bound up with every act that any violent deed jnvolves a tearin up by the roots of half the order of the worle. "visdon is founded upon justice; rut justice, to the wise man, is more a scrupulous quality in the mind than the doing of expedient acts upon simers." lamlet is neither weak nor unpractical. What he hesitates to do may be necessary or even just, as the world goes, but it is a 
defilement of his personal ideals, Death seems preferable to both actjon and existence. 'Hamlet's weapon in baffling Fate and his uncle is his justice, his precise scrupulousness of mind, the niceness of balance which ives everything he says the double-edge of wisdom. "The knowledge that the sword will not reach the real man, since damation comes from within, arrests his hand." The mercy of Iamlet leaves Claudius free to plot his death; the swiftness of ramlet gives claudius a hand and sword to work his wiIl.

Herbert Beerbohm Iree ${ }^{1}$, who played the role of Hamlet hundreds of times before Iondon audiences, describes a Prince who retains his lasting hold on our sympathies through his eternal].y human qualities. Ife is a man of many facets, everythin by turn and everything sincerely. His sensitive nature shrinks from the boorish court, and he sickens at the sight of his mother's faithlessness. After the Ghost's departure, Eamlet behaves as any highly wrought youn man would behave on hearing of the terrible fate of his father. He is on fire to sweep to his revenge. Here the actor should make clear to the audience that physical exhaustion prevents Famlet from carrying out the impulse of his mind. The weakened physical machine is unable to respond to the promptings of the mind. Hamlet's passion reaches its climax in the words, "O villain, villain, 1. Tree, Herbert Beerbohm, $\frac{\text { phoughts and After-Thoushts, }}{\text { pp. 124-153 }}$ 
smiling, damned villain!" His sword falls back in its scabbard, and he takes out his notebook. His strength spent, subtlety takes the place of action. The mind is stroneer than the body. The Prince takes an intellectual and painful deli ht in exercising his incenuity and wit on the various dupes of his feigned madness. He is, in fact, always the artist, the literary man who makes copy out of his own emotions for his own edification. The whole tracedy of Hamlet's life is bounded in the words, "There's nothing either good or bad but thinking makes it so." The man who most succeeds in life is he who is capable of seeing only one side. Hamlet wanders from the high road of fixed purpose into the by lanes of philosophical contemplation. After the players' scene when he cries, "O what a rogue and peasant sleve arn I" here again the artist is paramount. Instead of rushing to his revenge, he chews the cud of his wrath. Here the actor should suggest that Hamlet has spent his energy in vain unpackings of his heart in words. The sickness which afflicted the Prince was a kind of intel lectual burrowine which has laid many a noble nature low. Thoucht is the creat destroyes.

Excessive strength is the theme of shakespeare's tragedies, accordine to Frank inathews. Hanlet is too great for his time. One reason for the immortality of the play is that all Hamlet's meditations are as old as 
the hills. "Wediocrity assures them a fame denied to difficult greatness." The chief picture of Hamlet shows him making the most obvious reflections on the skull of Yorick. Because he is a spectator, he is in touch with the audience, a fault in traedy. "He interprets the Iragedy, which is part of the Pantomine, instead of controllins it, and he is the victim of his own meditations." Proof of the vagueness of his character lies in the fact that coethe, Coleridge, and Schlegel, who had little in common with the Elizabethan Englishman, identified themselves with him. ${ }^{1}$ "The interest of the universal, not the particular, dominates with Ianlet .... not his mother's sin but the frailty of women,"Sir Edmund $K$. Chambers writes. Mhrough his character we see the tragic ineffectiveness of the speculative intellect in a world of action.

Admitting quite frankly that he prefers reading shakespeare's plays to seeing them on the stage, Logan Pearsall Smith talks delightfully, among many other topics, of Shakespeare's self-revelation in the character of Hamlet. The fact that we cannot explain Hamlet, that he seems incapable of explaining himself, is perhaps what makes this imaginary being seem in a way more real than any real person who ever 1ived. The poet's detachment from

1. Ralli, op. cit., pp. 357-358

2. Ibid., $\overline{\mathrm{p}} \cdot 218$ 
existence, which would naturally result from his habit of philosophic meditation, his "way of seeing things in relation to the stars and the ceneral schere of things, and half dissolved as it were in thought," shows itself in Hamlet and the Hamlet-like characters, "sometimes in a sense of humorous absurdity and an ironic charity which seems like weakness, sometimes in an lincorrigible divine levity' as $\mathrm{kr}$. Shaw has well expressed it."I

The second Hamlet is a hero whose tragic trait was his moral idealism. He was portrayed by A. U. Bradey ant several other critics, among them HigEis, Adams, and Middeton kurry. .

Because Dr. Bradley's name is known and respected wherever the great dramatist is studied, it is well worth while to understand his theory of the substance of Shakespearean tragedy.

1. It is preeminently the story of one person.

2. The story leads up to and includes the death of the hero.

3. The suffering and calamity are exceptional and striking. They befall a conspicuous person, and they are unexpected and contrasted with his former happiness and glory.

4. It is the story of one in a high place.

5. The hero contributes in some measure to the disaster in which he perishes.

I. Smith, Logan Pearsall, on Reading Sakespeare, pp. 97-177 
6. There is an outward conflict of persons and groups, and there is also a conflict of forces in the hero's soul.

In the tragic hero we observe a marked one sidedness, a predisposition in some particular direction, a total incapacity of resisting the force which drews in this direction, a fatal tendency to identify the whole being with one interest, object, passion, or habit of mind. This is for shakespeare the fundamental trasic trait. The tragic hero is exceptional in position and nature. Although he need not be good, he must have so much of greatness that in his error and fall we may be vividly aware of the possibilities of human nature. The pity and fear which are stirred by his tragic story seem to unite with a profound sense of sadness and mystery which 1

is due to an impression of waste.

The whole story of Hamlet turns upon the peculiar character of the hero, without which the play would appear sensational and horrible..... Famlet appeals powerfully to our sense of the mystery of life, but so does every good tragedy; and it does so, not because the hero is an enigma to us, but because, having a fair understandine of him, we feel how strange it is that strength and weakness should be so mingled in one soul and that this soul should be doomed to such misery and apparent failure.2

Recognizing the popularity of the coleridge-Schlegel

theory that Hamlet's failure was due to an excess of the

1. Bradley, op.cit., pp. 3-23

2. Ibid., pp. $89-94$ 
reflective or speculative habit of mind, Dr. Bradley pointed out that their man is one who, at any time or in any circumstances would be unequal to his task. On the contrary, he said, "Hamlet was a man who, at any other time, and in any other circumstances than those presented, would have been perfectly equal to his task." ${ }^{I}$ The cruelty of his fate lies in the fact that the crisis of his Iife came on him at the one moment when he could not meet it, and when his hichest gifts, instead of helping him, conspired to paralyze him. "The cause of his irresolution was not directly or mainly an habitual excess of reflectiveness. The direct cause was an abrormal state of mind, induced by special circumstances - a state of profound melancholy." ${ }^{2}$ Before his father's death Hanlet's most marked characteristics were his exquisite moral sensibility, his idealism, and his intellectual genius. Under conditions of a peculiar nature, his reflectiveness certainly might prove dangerous to'him, and his genius might even become his doom.

Suppose a violent shock to his moral being; and suppose that under this shock, action being denied him, he began to sink into melancholy. Then, no doubt, his imasination and his generalizing habit of mind might extend the effects of this shock through his whole beins and mental world. If a sudden demand. for difficult and immediate action in a matter connected with the melancholy arose, this state micht well have for one of its symptoms an endless and futile mental dissection of the required deed. 3

1. Bradley, op.cit., p. 107

2. Ibid., p. 108

3. Ibid., p. 116 
The shock of his mother's true nature comin when he was grieving for his father's death and the realization that he must lock up this loathing in his heart induced a melancholy which accounts for his inaction and his own inability to understand why he delayed. Bradey echoed Victor Hugo's opinion that flamlet was a fatalist. $\mathrm{He}$ seemed to despair of forcing himself to action and to be ready to leave his duty to some other power than his own. Bradley's Hamlet is an heroic ficure, whose tragedy micht well be called that of moral idealism.

The historian Ralli calls Bradley the greatest living Shakespeare critic and one of the very greatest in the history of Shakespearean criticism. "Here, as with Coleridge," writes Falli, "is absolute critical truthand those writers should take warning who oppose the requirements of the stage and the need to please the audience against any attempt to know Shakespeare."I

"Ilonorable sensitiveness ruins tarnlet," according to Darrell Figeis ${ }^{2}$. The play is intellicible only when we regard the crucial part from the standpoint of the hero's feelings. Because of his overwrousht emotions, he is mentally overburdened; and his perplexity arises from the fineness of his susceptibilities. He spares claudius at prayer because to kill him then might frustrate his

1. Ralli, op.cit., p. 200

2. FiGois, Darreli, Shakespeare, A Study, pp. 213-215, 
second purpose - to discover whether or not his mother is innocent. When he recollects his actions, the emotion has passed away and only the discrepancies appear. Our perplexity is supreme when virtue, not vice, causes ruin.

In the preface to his edition of Hamlet, published in 1 1929, Joseph Quincy Adams of Cornell University, acknowledges that his interpretation of the play is deeply influenced by Pradley's analysis. According to Professor Adams, we must first understand the man Hamlet before we can hope to understand the play. His moral nature is notable for its loftiness and its exquisite sensibility. He feels the sreatest horror at the insincerity of his mother, the intemperance of his uncle, the politic craft of Polonius, at any slichtest deviation from the path of exact rectitude. As he moves amidst corruption and crime, he seems almost to possess moral grandeur. Equaljy notable is his intellect; and finally, his emotional nature is profound and easily stirred. As a result, he readily becomes "passion's slave". But these three qualities, always weIl developed in a truly great man, are not potentially tragic. It is shakespeare's custom to endow his heroes with some quality that will impair the judgment and so constitute a definite source of danger. Possessed in over measure it may, under special conditions, prove tracic. What then is the judgment-impairing quality possessed by 1. Hamlet, Edited by Adams, Joseph Quincy, pp. 173-277 
Hanlet in over measure? The young Prince possesses to a fatal extent idealism regarding human nature. Whe chost's revelation that his mother, whom he had idolized, was in reality an adulteress and perhaps a murderess crushed his soul and explains his strance condition of mopins and inertia throughout the rest of the play. Though Ilamlet doubted many things, he never doubted the righteousness of the task his father had placed upon his shoulders. The fundamental characteristic of melancholia, paralysis of will-power, explains why he failed to sweep to his revenge. After melancholia had rendered him unable to stir and his resultant mental suffering had forced him to seek an excuse for his delay, he prolonged his feigned insanity because it gave him the excuse that he was busy with important acting. The play, too, was only a poor excuse for his inaction. Hamlet failed to kill olaudius at prayer for the same reason that he had not killed him on a score of pat opportunities during the past two months. The aramatist's representation of the hero is consistent from beginning to end.

J. Midaleton lurry ${ }^{l}$ bases his criticism on impressions or sensations of Shakespeare. As he expresses it, he is "content to submit his mind" to the creat poet. Although Wurry is sentimental and pious in his attitude and turgid and overmannered in his style, yet. when he is moved, and 
he is moved by lamlet, his criticism becomes a celebration.

$$
\begin{aligned}
& \text { "Hanlet a coward!" Murry exclaims. "It is fantastic". } \\
& \text { The expectancy and rose of the fair state, } \\
& \text { The glass of fashion and the mould of form, } \\
& \text { The observed of all observers } \ldots \ldots \text {. } \\
& \text { IJI, i, 160-162 }
\end{aligned}
$$

He is all. that Ophelia says of him and more to us. Our love and our imagination make no mistake. Ie cannot be a coward, but he can be afraid. The appearance and speech of the chost convulse him with a new and hitherto unknown terror of the after-life. Henceforward death has a new and awful meaning for flamlet. The chost has done a double work: to reveal the murder and command revenge, and to implant in his son's soul that utterly new horror of death which will for a time prevent him from taking revenge. Only two non-accidental causes could make him hesitate: this new fear of "somethins after death," and obedience to the supreme demand of Christ, "Resist not evil." The former is the main dramatic motive of delay, but the latter is present as an overtone. Flamlet's innocence, that which we have so Iong as we believe in somebody as good, just, and permanent, is shattered. God is gone, or his evidences are; and there is no longer a center of certainty to which Hamlet's feelings and his thoughts are bound by law to return. Nothin less than a new Order, a new Law; and a new cod will serve his turn. The marvel is that we feel that he finds it, or 
that he incorporates it. "The answer to the riddle, Whether 'tis nobler'? is himself in his own final spontaneity. He may not know, but he is." Hamlet conquers a fear of death which circumstance has conquered for us, and at the duel, he is a free soul. He has forgotten his revenge upon the Kine. Thus only could the Hamlet of Act $V$ have killed the Kino at all. From "But that the dread of somethine after death" to "Absent thee from felicity awhile" is the utmost progress of which the human soul is capable.

A third Hamlet - one possessed of passionate weakness and indirectness of will - is painted by Frank Harris and W. F. Trench.

Harris, the astoundingly audacious "personality builder," assures us that Shakespeare, gentle, sensuous, and essentially feminine, could not depict a man of action, but in all his plays presented one man - himself. ${ }^{1}$ In the same way, he could paint only one woman, the object of his idolatrous passion, Mary fitton. Whenever Shakespeare was excited by personal feeling, he spilled himself into this or that character almost indifferentiy. Faced. with the fact that he had been befooled and scorned by his friend, William Herbert, and his mistress, he poured out his heart in the play of Ilamlet. After the betrayal 1. Harris, Frank, The llan Shakespeare, pp. 200-206, 
he went about nursing dreams of revenge and murder. Disillusion had deeper consequences, however. Forced to see other men as they were, he tried for a moment to see himself as he was. The outcome of that objective vision was the character of Hamlet, a masterpiece of self-revealing. Yet when he wrote the play, nothine was clear to him. To the injury of self-respect he had hung on with Herbert, hoping to build asain the confidence which had been ruined by betrayal, while brooding all the time on impossible plans of revene. Action had been "sicklied o'er with the pale cast of thought," and so Hamlet became a type forever of the philosopher or man of letters, who, by thinkine, has lost the capacity for action. Feeline that his irresolution and shrinking from bloodshed were in themselves nobler than action - half excusing, half realizing himselfhe brought forth his noblest work. To Hamlet his mother's lechery was horrible, because Hamlet-Shakespeare had identified certrude with Mary fitton. In comparison with his modest poet-rival, Claudius-Herbert is mildew'd and foul, a satyr to Hyperion. In the play Ilamlet's bitterness towards the aveen is the bitterness of disappointed love. To have her repent is more important than to slay her seducer. The passionate, melancholy aesthete-philosopher the play presents, then, is not only Hamlet but his creator as weil.

Mr. Harris' whole book is vastly entertaining, taken either as a study of the relations of literary art to life, 
or as the first of those intimate biographies the twentieth century reader applauds. It cuts both ways. In Hamlet character interest completely submeres 1 that of incident, Trench states. An idealist is brought face to face with reality and forced to play a man's part in a simple and primitive conflict. Responsibility deteriorates Hamlet. Formerly religious, he now curses his birth; before sreatly refined, he becomes obscene; charged to kill one, he is responsible for the death of several innocent persons; once scrupulously moral, he Grows indifferent to homicide. Tamlet fails through a definite defect in his will. He decides on a course of inaction and incurs the penalties which arise inevitably from the weakenine of will. It is hard to understand him, as shakespeare found, and he cannot understand himself. IIs whole life is changed beyond his recognition the philosopher must be a politician, the moralist a murderer, the theorist a practical man. He doubts the Ghost's identity and plans the mousetrap to give himself an excuse to postpone. After the play scene, he discovers the madman's impulse to kill; his suicidal tendencies become homicidal though he does not think of killing Claudius. Hamlet knows that he kills Polonius undeliberately, and he does not repent but feels he has acted as a scourge in the hand of cod. Confident in this 1. Ralli, op.cit., pp. $342-343$ 
overruling Power, he repudiates voluntary action. He was given the chance of doine his share, but he failed and wrou ht disaster. When Ophelia deplores the loss of his reason, Shakespeare is mocking her; and when the reader deplores the hero's death, Shakespeare is mocking him. The fourth Hamlet, Benedetto Croce's, is a man who, injured spiritually, begins to die internally.

Hamlet is not the key to Shakespeare's other plays, thinks the Italian philosopher. It is rather the expression of a distinctive state of the soul. It expresses distaste for life, but life is thought and will, each of which creates the other. When we are injured spiritually, this process is interrupted and a sort of death ensues. Hamlet would have avenged the host had he not begun to die internally. Unable to understand the nature of his malady, he encouraged it instead of combatins it; and he effected vengeance as if by chance. Croce finds less philosophy in Hamlet than in the other plays, because it is more perplexed and vasue. ${ }^{1}$

A fifth Hamlet - a victim of nervous shock who "expresses himself wron ly" - emerges from clutton-Brock's analysis. ${ }^{2}$

Although he deplores the habit of hunting Hamlet's motives as if the play were a history of real persons,

1. Ralli, op.cit., p. 393

2. Ibid., $\overline{p p \cdot 42 I-422}$ 
Glutton-Brock himself is a deeply subjective and impressionistic critic. He finds the character of Hamlet entirely convincing. As he acts, so we feel he would act; and no play produces a stronger feeline of certainty. The tragedy is that he does many thin s that trouble us and that seem contrary to his real character, and yet we never doubt that he would do them. While we are experiencing the work of art, we hardly notice the delay because we are absorbed by Hamlet. The first sign of mental disorder occurs at the appearance of the chost. The essence of the tragedy is that his irrelevance, the result of nervous shock, causes many deaths instead of one and causes Hamlet to express himself wrongly. Out of extreme hatred he spares Claudius at prayer. He wishes to enjoy the pleasure of killing him and must be in a rage to do it. What he hates is less claudius than a beastliness in life that Claudius represents. Action cannot satisfy a mind shocked by life itself.

In Hamlet is a peculiarity of values never before attempted, a certain way of feeline, thinkins and acting, unknown before, but since valued by the world. His virtues prevent his acting effectively, but his capacity for sufferins is more to be valued than the common hero's effectiveness. I

A sixth Iiamlet, victim of an Oedipus-complex, appears next through the analysis of Dr. Lrnest Jones. 2

Scientist thouch he undoubtedly is, Dr. Jones fits snugly into the present chapter; for he psychoanalyzes

1. Ralli, op.cit., p. 422

2. Jones, Ermest, "The Oedipus Complex," American Journal of Psycholosy, 21:72, 1910 
the troubled Dane with as much gravity as S1gmund Freud would employ in one of his most serious cases. Iet us imagine Hamlet, deeply distressed because he revolts from a deed which it is plainly his duty to perform, seekins out Dr. Jones for assistance. It does not take long for the psychologist to discover his patient's malady. He sees that Hamlet is tortured by some mysterious inhibition. Evidently at heart he does not wish to carry out the task. When he realizes Gertrude's sensual nature and her passionate love for her son, Dr. Jones begins to believe that in Hamlet's early affection for his mother there was an erotic element, and that perhaps often he had longed to take his father's place with his mother. Now Claudius has won the place that Iamlet as a child had desired. Paralysis of will and action have resulted from his fear to explore his own mind, for he disobeys the call of duty to slay his father's murderer because it is linked with the call of nature to slay his mother's husband. Hamlet's is a plain case of the oedipus-complex.

The seventh Hamlet is a man whose mental coming of age occurs during the play. Oscar Firkins describes him. "The inadequacy of the old Hanlet theories which is implied in the permanence of the problem," sighs Firkins, "drives men to seek relief and respite in the greater and more glaring inadequacy of the new." He returns 
from the new to the old with the decision that no single theory can disentangle Hamlet. The Prince did not lose his mind but found it. In the shock of the catastrophic revelation and in the excitement, almost exhilaration, of that discovery, he forgot a crime and isnored a duty. Before the death of Hamlet's father, Denmark was decent, godfearing, conventional and stodgy. Hamlet was the perfect lady's idea of the perfect gentleman. His mind was unenfranchised, unawakened, unoriginal, and his eye incurious and incredulous to evil. The first shock, the revelation of his mother's capacity for lust, reduces him to despair. The second, the knowledge of his father's murder, produces anguish which relieves itself by mimicry and distraction. In the second act we see Hamlet actually having a good time, and that good time is almost the unravelment and elucidation of the play. It is the delight of the aroused, active, and capable intelligence in the freedom, swiftness, and destructive efficiency of its own action. Hamlet has found his mind. Shakespeare undoubtedly held that the enlarement and derangement of a mind might be simultaneous. The peculiarity of Hamlet's case lies in the fact that the supreme intellectual crisis and the supreme moral and emotional crisis of his life, being products of the same cause, have occurred at the same moment. What will be the result of this cancidence? If he be primarily a thinker, the thinker will command 
the sufferer and the moralist. Hamlet, then, is not diverted from the act by thoughts about the act itself. Ile is distracted by other thoughts. The interests on which his mind fastens are prevailingly general or abstract. The abstract reasoner, the disinterested and impersonal observer grows as the play continues. Real emotion undoubtedly exists, but the raiment of emotion is often donned by nervous excitability. He scarcely hates Claudius now; he is scarcely interested. The episodic, inattentive, contemptuous murder of the King is in itself a slicht. The stab is preceded and followed by a revelation of indifference which is in itself a stab. Hamlet has passed from a philanthropist to a misanthrope. Reconstruct your world to fit an enormity, and in a world so reconstructed, the enormity will lose much of its disgrace and unexpectedness.

With the eighth and last Hamlet to be considered in this chapter we return to the second camp, for he is a courageous man defeated by fate. Iascelles Abercrombie paints him. 1

Accordin to this critic the Frince's fate is a psycholofical disaster. We see tramlet as he sees himself; and we also see him as the living hamony of an immense complexity of events. Iveryone knows how he sees himself:

1. Abercrombie, Lascelies, The Theory of Poetry, 
I do not know

Why yet I live to say "this thing's to do."

IV, iv, $43-44$

He bitterly despises himself for his failure to act; he can but thinle and talk about acting and return to his self-contempt. The critics have called hin the very ficure of moral vacillation, and Hamlet himself agrees with then. Ihis hardy accounts for his prestige. It is certainly not as a contemptible ficure that he has impressed the world; it is odd that the comentators should have left out his unistakable heroism. Famlet's difficulty in makin up his mind tiat he should kill the Kino is due to his realization that desire is easily mistaken for duty. At length convinced, by intuition rather than by proof, of claudius' cuilt, he upbraids himself. for a delay which simply does not exist! There is no - moment in the play in which we see ramlet failin to kill the King. He rejects the one opportunity because it is too favorable to his enemy's hereafter. Those contemptible delays exist wholly in his own mind. The whole world is out of tune while his desire remains ineffective, for this desire is justice. Why is justice less able than the brute process of events? There must ve sorne reason.

The fearful conclusion leaps at him. Je hinself is the reason why his desire remains unacted; he is unworthy of it. Justice would have been done had not his cowardice delayed it. This is the fanous delay we hear about in Fiamlet's soliloquies; it is the trasic invention of his own wounded mind.... In the play we see exposed the trapped anguish of human nature found weaker than events.I

I. Abercrombie, op.c1E., p. 304 
To attempt a summary of such disparate views as the eight which we have considered in this chapter will perhaps seen audacious. I believe, nowever, that such a puling together will prove profitable.

make the idealist confronted by a problem to which

he is not equal," I wrote at the close of chapter II, "and five him 'a craven scruple of thinkins too precisely on the event ${ }^{\prime}$; and in the coethe-schlesel-coleridge compound which results, will be found the Hamlet that delichted the aesthetic fancy of the nineteenth century romantic critic."

Now at the close of Chapter IV I write: Suppress the words "cruven" and "to which he is not equal", and to the character that is left add courage and heroism. In the compound which results will be found the flamlet that has delishted the aesthetic fancy of the twentieth century romantic critic. 
CONCLUS IOIN 


\section{CORCLUSION}

The journey through Hamlet criticism from 1774 through 1936 is over. We have seen the flanlets of the romantic critics f'rom Richardson's Prince whose moral fineness recolled before the bloody duty of revence to lidaleton murry's mystic who reached the exaltation of conficence in an hereafter. We have seen the flamlets of the realistic critics from Rumelin's hero whose character was incongruous with the old tragedy of blood to bover ilson's courageous and efficient Dane who battled his way to victory.

As we glance back over the ground. we have covered, we may trace in the reaction of the critical mind towards the play not only the shifting trends in Shakespeare criticism but also the broad lines of the history of Western thought. vriters and actors in each generation have been drawn to the tragedy by the irresistible appeal of the idealism in the role of the hero; and, however they have interpreted tre nature of the Prince, they have stamped hin with the philosophy of their period. The

"sensilility" of Richardson's Hamlet is not only the characteristic quality of his creator; it is the mind of the late eighteenth century. Mhe noral idealism of Coethe's Farlet is not only the idealism of roethe; it is the attitude of the metaphysician. Coleridge's morbidly reflective hero is coleridge himself, for did 
he not declare that he had a smack of the royal Dane in his nature? We have only to look around us in the period of great romanticists, however, to find critic after critic slipping into the role of the prince of philosophical speculators. Hazlitt, like coleridge, saw himself in the hero, but he went further to state that Famlet is Everyman. The cynical Hamlet of Gervinus is tinged with the sickness of the man who described him, the bitterness of the German thinker of the mid-nineteenth century, who, feeline himself unequal to the real worlc, was repelled by it. Lanier's Frince, the moral interrogation point who snswers life's questions by askin another question, is the confused slreptic of the late nineteenth century - the man who is impelled to doubt but who desires to believe.

Towards the close of the nineteenth century we have seen the scholar focusing the light of history on shakespeare's method and materials and on the traditions of the Hizabethan stage. Consciously or unconsciously, realist and neo-romanticist alike have accepted the findings of the historical critics and have absorbed them into their interpretations. Swinburne clearly understood the influence of Senecan tragedy on Iizabethan drama; but, without underestimating that factor in the genesis of the pley, he described a Hamlet possessed of his own fatalism, the hopeless stoicism of one trend of late nineteenth century thoucht. Shaw's Hamlet, in whom the conmon personal passions 
are superseded by wider and rarer interests, is the Irish dramatist himself, who cannot resist that sudcen appeal to universal considerations which is called philosophy or humor. Is he not also the reader who admires the mind of shaw, which will not stay on the narrow track of plot? Nasefield's Famlet is an English poet in a world governed by the enemies of intellect; Tree's, an artist who makes copy or his own emotions for his ow delight; Bradey's and wurry's, any moral idealist imprisoned in a materialistic society.

It is difficult to chart the strean of twentieth century thought; perhaps an authoritative classification can be made only with the perspective of a nother generation. It is obvious, however, that through the creative criticism of realist and romanticist alike, we see as many Iamlets as there are contemporary types of heart and mind.

Hanlet is a mirror which has given back the glorified and idealized image of each age. As the scholar has so admirably proved, the play was written for the preat mess of Elizabethan playsoers. It was an amazincly popular piece of dramatic art with Burbage and Bettertion in the leading role; and it has remained a drawing card in the theater through Garrick, Kemble, Booth, inacready, Irving, Tree, Bernhard, and Forbes-Robertson to Walter Fampden, John Barrymore, isme Percy, Leslie Howard, and John Gielsud. 
I do not wish to minimize the invaluable contribution of the historical critic. I should like merely to point out the danger in his assumption that he must declare war on all creative critics, whether they be realistic or romantic in their approach. So lons as he remembers that his study is a means towards an end - a play that is more intelligible to the playgoer because it is staged and acted more intellicently - the scholar performs a necessary service to the theater. When he pursues his method to an extreme, it becomes an end in itself - a delichtful gane for the few.

Let us subject a particularly positive member of the more radical group of historical critics to a practical test. In the Publication of the Hodern Languase Association for July, 1933, Hazelton Spencer wrote:

1. The historical view of the Prince's character steadily wins its way.

2. The romantic critics are pretty generally discredited. $\mathbb{M r}$. Bradley's ingenious essay is still admired because it is an artistic performance in itself, but few now believe that Bradley's Hamlet is Shakespeare's.

3. In the li ht of lizabethan demonolosy, it is well understood that doubt of the chost's authenticity adequately motivates the Prince's delay up to the Mousetrap; that he spares the praying King, as he 
plainly says, only that his revene may be complete; and that from this point on he simply has no chance to kill his adversary till the last scene.

Here are the test questions, which, in Nr. Spencer's absence, I shall try to answer:

1. Iith whom does "the historical view of the Prince's character steadily win its way"?

With one small group of the historical critics - the most notable members of which are ferder, lorgan, stol] and Dover Wilson. I find surprisingly little difference between the Hamlut of the downright romanticists and the Hamlet of such realists as Raleigh, Shaw, Quiller-Couch, Santayana, and kobertson. I have yet to see or to read of a successful performance of Hamlet inspired by the critical opinion of Professor stoll or Dover filson. At the close of the nineteenth century, it is true, Barrett vendell played a Famlet who strongly resembled Appleton lorgan's "truly En lish prince for whom a vendetta had no time Iimit"; but hendell's interpretation was not generally popular, and it won more favor with horgan than with other critics.

2. By whom are the "romantic critics pretty well discredited"?

By one small eroup of the historical critics, which, for convenience, we might call the stoll-Uilson school. Elsewhere I have quoted Augustus Ralli's statement with Soliloquies," P.M.I.A., 9:247, JuIy, 1933 
regard to Dr. A. C. Bradley; here I shall simply remind the reader that $\mathrm{Mr}$. Spencer is including in his list of those "pretty well discredited" such men as Yeats, Masefield, Pree, Croce, Logan Pearsall Smith, Adams, and liddleton Nurry

3. How can "the licht of ilizabethan demonolosy" be thrown on the modern interpretation of the play?

If the play is a supreme masterplece, and, critics of both schools agree that it is, it is one that each successive age can interpret in terms of its own moods ano needs. Tigures of literature and history live in the thoughts of men on the condition that they change their aspect. Ifumanity is interested in past ages and dead authors only in so far as it can attrikute to them its own passions and thoughts. That men are able to go on doing so - seeing now this, now that in a book or play - is proof of immortal creation. Only to the historian, then, would "the licht of Elizabethan demonology" be illuminating. If the play is dramatically sound (Rumelin and T. S. Eliot expressed doubt about it), the audience will understand it and enjoy it without realizing they need more light. The experiment that would convince me of the sounchess of fir. Spencer's thesis would be a performance of Hamlet exactly as jover Wils on has outlined it in that Happens in Hamlet. At the risk of disrespect to my intellectual betters, I must add that Frofessor Wilson should try to be on hand to lecture 
between acts. Otherwise the audience might leave the theater more mystified than enlightened. An ilizabethan performance of tramlet would be interesting to a select coterie of the initiate; it could have no general appeal. As another illustration of my point, let us consider Professor Stoll's Shylock. A comic Jew, a butt and a fool, might win favor in fermany today, as stoll has proved he did when the Merchant of Venice was first performed; but on the English or American stage he would be incomprehensible. Today he seems to us a tragic figure; I do not know how we shall interpret him tomorrow. The critic who has surveyed the changing aspect of Famlet from 1774 through 1936 will surely hesitate to speak dogmatically. We know how great minds have interpreted Shakespeare's hero in the past; we know how nnany minds interpret him today. A successful twentieth century performance of the play must reflect some facet of contemporary thought. The last word has not been spoken, nor can there be a note of finality so long as Hamlet continues to be read and performed, for no critic is Bifted with the prescience to describe the lamlet of tomorrow. 
BIBIIOGRAPHY

、 


\section{BIBJIOGRAPHY}

POOKS

1. Abercrombie, Lascelles, whe wheory of Poetry,

New York, Harcourt, Erace and Co., 1926.

2. Adams, Joseph Quincy, A Iife of Villiam Shakespeare,

Boston and New York, Woughton Mifflin Co., 1923.

3. Bradley, A. C., Shakespearean pracedy,

London, iacmillan, 1904.

4. Brandes, Ceorce, Niliam Shakespeare,

London, Nacmillan, 1916.

5. Campbell, Lily B., Shakespeare's Pragic Heroes, Cambridse, University Press, 1930.

6. Chapian, John Jay, A lance Ioward Shakespeare, Boston, Atlantic ronthly Press, 1922.

7. Chief Ilizabethan Dramatists, Whe, Edited by Neilson, illiam Allen, ambridge, Toughton Ihfflin Co., 1911.

8. Coleride's's Shakespeare Criticism, Dited by Raysor, Thomas Midaleton, 2 vols., Cambridge, Harvard university Press. 1930.

9. Companion to Shakespeare Studies, A, Edited by cranville-Earker and Harrison, G. B., liew York, llacmillan, 1934.

10. Cunliffe, John Tracedy, New York, G. E. Stechert and Co., 1925. 
11. Dixon, W. Macneile, Tragedy, Iondon, Edward Arnold and Co., 1924.

12. Dowden, Edward, Shakespeare-His Mind and Art, Hew York, Harper, 1880.

13. Drinkwater, John, Shakespeare, New York, Macmillan, 1933.

14. Eliot, T. S., The Sacred Wood, London, Nethuen, 1920.

15. Famous Introductions to Shakespeare's Plays, Lited by Warner, Beverley, New York, Dodd, Mead and Co., 1906.

16. Figgis, Darrell, Shakespeare - A Study, New York and London, Mitchell Kennerley, 1912.

17. Gollancz, Israel, the Sources of Hamlet, London, Oxford University Press, 1926.

18. Great Critics, The, Hdited by Smith and Parks, New York, W. W. Norton and Co., 1932.

19. Farris, Frank, The Han Shakespeare ano His Tragic Life Story, liew York, Mitchell Kennerley, 1909. 20. Farrison, A. B., Shakespeare Under Elizabeth, New York, Ilenry HoIt and Co., 1933.

21. Hazlitt, William, Lectures on the Iiterature of the Age of Elizabeth and Characters of Shakespeare's Plays, London, Geore Bell and Sons, 1878.

22. Ianier, Sidney, Shakespeare and His Forerunners, New York, Doubleday, Page and Co., 1908.

23. Lawrence, Milliam Witherle, Shakespeare's Problem Comedies, New York, Nacmilian, 1931. 
24. Masefield, John, William Shakespeare, New York, Henry Holt and Co., 1911.

25. Masson, David, Shakespeare Personally, New York, E. P. Dutton and Co., 1914.

26. Hatthews, Brander, Jevelopment of the Drama, New York, Scribner, 1904.

27. Norgan, Appleton, Shakespeare in Fact and in Criticism, New York, William Evarts Benjamin, 1888 . 28. Hurray, ilbert, Hamlet and Orestes, liew York, Oxford University Press - American Eranch, 1914. 29. Ifurry, John Hiddleton, Shakespeare, New York, Harcourt, Brace and 0o., 1936.

30. Quiller-Couch, Arthur, Notes on Shakespeare's Morkmanship, New York, Henry Holt and Co., 1917.

31. Raleish, Walter, Shakespeare, New York, Wacmillan, 1907 .

32. Ralli, Ausustus, A Iistory of Shakespearian Criticism, 2 vols., Iondon, oxford Tniversity Press, 1932 .

33. Faven, Anton $A_{\bullet}$, A Hamlet Bibliosraphy and Reference Cuide, Chicaso, University of Chicaso Press, 1936.

34. Robertson, J. ..., ontaicne and Shakespeare, London, Adam and Chas. Plack, 1909.

35. Robertson, J.M., The Problem of Famlet, Iondon, Geo. Allen and Unwin, Ltd., 1919. 
36. Fobertson, J. H., The State of Shakespeare Study, London, Geo. Routledge and Sons, Ltd., 1931.

37. Saintsbury, George, Listory of Criticism, 3 vols., London, Blackwood, 1904 .

38. Santayana, reorse, "Tanlet," in Obiter Scripta, New York, Chas. Scribner's Sons, 1936.

39. Schucline, Levin I., character Froblems in Shakespeare's Plays, New York, Tenry Holt and Co., 1922 .

40. Shakespeare, Wilizan, Hamlet, Edited by Adams, Joseph Quincy, Boston and New York, Iouchton Iifflin Co., 1929.

41. Shaw, Ceorge Bernard, Dranatic Opinions and Essays, 2 vols., New York, Prentano's, 1906.

42. Smith, Logan Pearsall, On Reading Shakespeare, New York, Harcourt, Erace and Co., 1933.

43. Spurceon, Caroline F. E., Shakespeare's Imasery and what It Iells Us, lew York, Nacmillan, 1936.

44. Stoll, Imer Edear, Art and Artifice in Shakespeare, Cambridee, Jniversity Press, 1934.

45. Stoll, Elmer Ldgar, Shakespeare Studies, New York, hacmilian, 1927 .

46. Swinburne, Algernon Charles, A Study of Shakespeare, London, Milliam Heinemann, Ltd., 1929.

47. Ien Brink, Bernhard, Eive Lectures on Shakespeare, Translated by Iranklin, Julia, New York, Ienry Holt and co., 1895. 
48. Tolman, A. H., Talstaff and Other Shakespearean Topics, New York, inacmillan, 1925.

49. Tree, Herbert Deerbohm, Whoughts and AfterThoughts, New York and Iondon, Funk and Wagnalls Co., 1913.

50. rucker, Milliam John, College Shakespeare, New York, Lhos. Y. Crowell Co., 1932.

51. Wwelve Centuries of inclish Poetry and Prose, Edited by Newcomer and Andrews, Chicago, Scott, Ioresman and Co., 1928.

52. Variorum Shakespeare, VoI. IV, Ldited by frurness, Forace Howard, Hila., Lippincott, 1877.

53. Vende11, Barrett, William Shakespeare - A Study in Elizabethan Iiterature, New York, Chas. Scribner's sons, 1895.

54. Wite, Richard crant, Studies in Shakespeare, Boston and New York, Ioughton Mifflin Co., 1885.

55. Wilson, John Dover, What Happens in "Hanlet", New York, Vacmilian, 1935.

56. Hinstanley, Iillian, Hamlet ano the scottish Succession, Cambriage, University Press, 1921.

57. Yeats, Willian Butler, "At Stratford-on-Avon," in Essays, New York, Macmillan, 1924. 


\section{PERTODICALS}

1. Firkins, Oscar W., "What Happened to Hamlet," Worth American Review, 212: 393-403, 1920 .

2. Jones, Ernest, "The Oedipus Complex as an Explanation of Hamlet's liystery, "American Journal of Psycholouj, 21:72ff., 1910.

3. Spencer, Hazelton, "Seventeenth Century Cuts in Iamlet's Soliloquies," P.M.I.A., 9:257-265, JuIy, 1933. 




Teaching Record

Teacher of English and French - Welsh High School, Welsh, Louisiana, 1918 - 19; ITonsarrat Departmental School, Iouisville, Kentucky, 1919-21.

Teacher of French and Spanish - Louisville Girls' High School, 1922 .

Teacher of English - Western Departmental, 1922-23; Louisville Cirls' High School, 1923; $J$. M. Atherton High School for Girls, 1924 - 1937 . 